Article

\title{
Optimal Contracting of Pension Incentive: Evidence of Currency Risk Management in Multinational Companies
}

\author{
Jeffrey (Jun) Chen ${ }^{1, *}$, Yun Guan ${ }^{2}$ and Ivy Tang ${ }^{3}$ \\ 1 Department of Transportation, Logistics, \& Finance, College of Business, North Dakota State University, \\ 1340 Administration Ave, Fargo, ND 58105, USA \\ 2 College of Business, Clemson University, 105 Sikes Hall, Clemson, SC 29634, USA; yguan@clemson.edu \\ 3 Luxembourg School of Finance, Université du Luxembourg, 2, avenue de 1'Université, 4365 Esch-sur-Alzette, \\ Luxembourg; ivytang22@hotmail.com \\ * Correspondence: jun.chen1@ndsu.edu
}

Received: 17 December 2019; Accepted: 27 January 2020; Published: 3 February 2020

\begin{abstract}
Using a large sample of multinational companies (MNCs), this paper intends to explore whether executives' pension incentives will function as a mechanism of optimal contracting in motivating firm risk management. We find that granting more pension to executives is significantly related to the higher likelihood and intensity of currency hedging strategies in MNCs. This suggests that pension incentive should promote executives to more actively manage firms' risk. Such a positive relationship is robust to endogeneity and is more prominent in firms with strong shareholder power. We further explore the contribution of currency hedging induced by pension incentives to shareholder value. Supporting the hypothesis of optimal contracting, our results indicate that pension incentives play an important role in reconciling managerial risk preference and shareholder value creation.
\end{abstract}

Keywords: pension incentive; currency hedging; multinational companies; firm value

\section{Introduction}

How to financially motivate executives has attracted a great deal of attention in literature. This is not surprising, as self-interested managers-along with their substantial influence on firm policies-are found to extract private benefits at the expense of shareholders, and therefore a well-designed compensation contract is critically important for shareholders who seek to maximize their value. However, the dominant theme of existing literature in executive compensation only focuses on traditional components, such as a base salary, bonus, and equity compensation (stocks or options), but overlooks another important piece, pension benefits, which mainly include retirement plans and deferred compensation. As emphasized by Jensen and Meckling (1976), the ingredients of an ideal compensation package for managers should include both equity-based and liability-based instruments. The binding claim in liability-like benefits is expected to influence managerial risk-preference, mitigate the agency cost, and hence affect possible value reallocation among stakeholders.

Compared to the widespread practice of pension plans or retirement benefits, studies regarding to the role of such liability-based compensation are generally scant. Edmans and Liu (2011) and Sundaram and Yermack (2007) are the earlier studies that explore liability-based instruments in compensation from theoretical and empirical perspectives. Particularly, Edmans and Liu (2011) propose that pension compensation outperforms cash compensation and helps solve the agency conflicts between shareholders and debtholders. Sundaram and Yermack (2007) document that liability-based compensation accounts for an important portion of executives' total wealth, motivating them to invest conservatively and therefore reducing default risk. Recent studies suggest that executives' 
pension benefits are associated with lower CDS spreads (Wei and Yermack 2011), lower R\&D investment and financial leverage (Cassell et al. 2012), lower cost of private loan financing and fewer restrictive covenants (Anantharaman et al. 2014), cash holding (Liu et al. 2014), and managerial risk-taking (Anantharaman and Lee 2014).

The research on incentive design is important not only because it, per se, targets a fundamental business contract, but also yields instructive and practical insights into how an agent's risk attitude is financially effected and how the stakeholders are exposed to the related consequence. As noted above, there is a paucity of research on the nature of pension incentive and its impacts on the risk management of firms. For example, Anantharaman et al. (2014) found that firms with more pension incentive are charged with lower cost of debt financing and fewer restricting covenants. Cassell et al. (2012) and Liu et al. (2014) observe that the use of pension incentive is associated with lower R\&D investment and more cash holding. However, none of them provide an explicit link between pension incentive and corporate risk management, particularly with the interplay of shareholder governance. By utilizing the data of currency hedging strategy used by the MNCs, this paper aims to investigate a direct impact of pension incentive on the managerial decisions. Additionally, the unique and hand-collected hedging data across the industries offer us a chance to have an unambiguous view of active risk management.

Corporate risk management, particularly hedging strategy, has become a critical dimension of financial policy and also attracted a lot of research interest. The study based on the Wharton survey of derivative usage shows that a growing number of CEOs view financial derivatives as indispensable tools in managing firms' risk (Géczy et al. 2007). The academic research also documents that hedging increases firm value by overcoming the market imperfections, such as deadweight costs related with bankruptcy risk, aggressive tax region, the underinvestment problem, and high cost of capital (Smith and Stulz 1985; Froot et al. 1993; Rogers 2002; Campello et al. 2011). More importantly, the literature suggests that executives' compensation incentives are an important determinant of corporate hedging. The traditional view of financial incentives focusing on equity compensation predicts that granting stocks or stock options will motivate managers to overcome risk aversion. In contrast, Sundaram and Yermack (2007) argue that executives' pension benefits would generate different incentives. The nature of unsecured and unfunded pension liabilities may expose managers to firm risk due to a lack of diversification and may result in a devastating loss of personal wealth in the case of firm bankruptcy. Since hedging reduces a firm's cash flow volatility and consequently lowers the likelihood of bankruptcy, it is plausible that CEOs who hold a larger amount of wealth in pension will be more actively involved in managing firm risk through hedging.

This study focuses on currency risk management by using foreign exchange derivatives, because Géczy et al. (1997) investigated the use of derivatives for a sample of Fortune 500 non-financial firms and found that currency derivatives are used most frequently by corporations. Foreign currency exposure is also considered as a major source of risk by the US firms (Bodnar et al. 1998; Krapl and White 2016). It is arguable that a firm may have little need to use foreign currency hedging if it has no relevant foreign currency risk. Therefore, in the spirit of the literature (Graham and Rogers 2002; Campello et al. 2011), we identify the multinational firms with ex ante exposure to foreign currency risk in this study. However, we also followed Doukas and Pantzalis (2003), to consider the case that a firm might be subject to foreign currency risk due to the competitive environment. To do so, we included keywords related to foreign currency and foreign exchange market risk in our textual searching program to read if firms explicitly state their foreign currency exposures in 10-K filings.

In this paper, we first examine the relationship between pension incentive and hedging propensity. Based on the sample retrieved from the COMPUSTA Segment database and matched with EXECUCOMP executive pension database, our investigation covers 1625 US firms from 2006 through 2015. Hedging data are collected from 10-K filings compiled in the SEC EDGAR database. We find that a higher level of pension incentive is associated with a higher probability of adopting currency hedging strategy. A one-standard-deviation increase in the pension benefits in dollar amount leads to an increase of $2.2 \%$ in hedging probability. Meanwhile, a one-standard-deviation increase in the 
pension proportion in CEO total compensation increases hedging probability by $6.5 \%$. In addition, by using the notional amount of hedging position, we find that a higher level of pension incentive also brings about a larger position of hedging. For one percent increase in CEO pension relative leverage, the hedging position rises by 40 basis points of total assets $(0.4 \%)$, an equivalence of USD 35.95 million investment in foreign currency derivatives.

As with most studies in business research, the endogenously determined incentive might be a potential concern in our research. However, the significant and positive relation between hedging activity and pension incentive remains consistent when we perform robustness checks, instrumental variables (IV) model to control for endogeneity. The results from the robust models suggest that endogeneity cannot explain away the positive impact of pension incentive on hedging activity, and the inference from the baseline models is unaffected when correcting for endogeneity.

Given a positive relation between pension incentive and hedging activity, a natural question to further explore is whether this relation is contingent on governance mechanism. To answer this question, we propose the optimal contracting hypothesis. Our analysis suggests a more prominent influence of pension incentive on hedging for the firms with strong shareholder power than those with weak shareholder power. Furthermore, we employ the model of Faulkender and Wang (2006) to quantify the impact of hedging on firm value, augmented with pension incentive and governance mechanisms. The empirical evidence shows that one dollar of investment in existing hedging position generates USD 0.374 to shareholders and one dollar increase in hedging position creates an additional value of USD 0.204. More importantly, we find that the marginal impact of pension incentive on the value of hedging is higher for the firms with strong shareholder power, which supports the optimal contracting hypothesis.

In the extant research, the influence of pension incentive on active risk management (e.g., hedging) has not been given enough attention. Belkhir and Boubaker (2013) and Krapl and White (2016) are the two of few studies that have explored this area. Belkhir and Boubaker (2013) examined pension paid to CEOs in the US bank holding companies and find that higher CEO pension holdings relate to higher use of derivatives to hedge against banks' interest rate risk. They explain that pension compensation binds the banks' default risk with the executives' interest and curbs their excessive risk-taking activities. Krapl and White (2016) document a negative relation between foreign exchange exposure and pension-based compensation paid to executives including CEOs, CFOs, and other top managers. These results imply that pension compensation encourages executives to reduce cash flow volatility and hence lowers firms' exposure to foreign exchange risk.

Our findings are consistent with Belkhir and Boubaker (2013) and Krapl and White (2016), but this study differs from them. First, we build a large sample of companies that span across a wide array of industries, rather than only financial institutions. This large sample recognizes the possible heterogeneity and produces more applicable conclusions. Moreover, as suggested by Krapl and White (2016) foreign exchange exposure is a major source of risk to most of the US firms. Our focus on currency risk management reflects such an urgent demand in the age of globalization. In addition, our hedging data allow a direct look at the financial derivatives used in risk management. This study supplements the literature with the supportive evidence and further casts new light on the long-debated contracting theory of executive compensation.

In this paper, we fill the void in the literature by empirically examining the impact of pension incentive on firm risk management and how such influence is contingent on governance environment. Our study contributes to the literature in the following ways. First, we document a significantly positive impact of pension incentive on foreign currency hedging implemented by the multinational firms. Second, this paper complements the literature of compensation design by providing new evidence to support the optimal contracting hypothesis. Our analysis suggests that pension, the liability-based instrument adopted in the environment of strong shareholder power has a more pronounced impact on executives' hedging decisions. In addition, this study also enriches the existing hedging literature. After controlling for other well-documented determinants, we find pension incentive plays a remarkable 
role, which is different from the equity-like compensation, in determining managerial risk attitude gauged through the hedging strategy. Finally, this research relates to the literature of risk management and we add the new insight to understand the active currency hedging strategy used by the multinational companies in creating shareholder value.

The remainder of this paper is structured as follows: Section 2 will review the literature and develop the testable hypotheses. Section 3 describes the sample, the variable constructions, and the summary statistics are also provided. Section 4 discusses the model specification and reports our main empirical results. In Section 5, we present an extended analysis on the value of hedging, interacted with pension incentive and governance. Section 6 concludes the paper.

\section{Relevant Literature and Testable Hypotheses}

\subsection{Equity-Based Incentive and Managerial Risk Preference}

There is a large and growing literature on executive compensation and its influence on managerial incentives, corporate financing, investment, and firm value (Peng and Roell 2014; Gormley et al. 2013; Bereskin and Cicero 2013; Liu and Mauer 2011; Billett et al. 2010; Coles et al. 2006; Carpenter 2000). Practically, an executive compensation package consists of the short-term and long-term components. The former mainly includes salary and bonus, whereas the latter refers to restricted stock grants, grants of stock options, long-term incentive payouts, and other compensation. Although the annual salary can be partially decided by the past performance, and the bonus component is based on various metrics of accounting information (i.e., return on assets, return on equity, sales growth or other according measures relative to the industry or competitors), these two components are not the primary solutions for the shareholders, intuitively, to maximize the their value since neither of them are directly linked to stock returns, which is presumably concerned most by shareholders. As Jensen and Murphy (1990) point out, the present value of current and future increases in salary and bonus represents a small fraction of total financial incentives. Meanwhile, under the framework of principal-agent theory, incentive contract is designed to reduce the agency conflicts between risk-neutral shareholders and risk-averse managers. For this reason, compensation packages containing long-term incentives, particularly equity-based instruments, attract more interests and explorations.

Unlike well-diversified shareholders, managers cannot diversify their human capital. As a result, they tend to forgo positive NPV but highly risky projects when their benefits from an increase in firm value are lower than their costs associated with greater firm risk. Equity-like compensation is viewed as a mechanism to reduce this underinvestment problem through aligning the interests of managers and shareholders (Jensen and Meckling 1976). Smith and Stulz (1985) and Guay (1999) also suggest that equity compensation motivates managers to overcome risk aversion and hence induce optimal risk-taking behaviors. In particular, Smith and Stulz (1985) show that the risk-related incentive problem can be controlled by rewarding managers with stock options or common stocks to structure their wealth as a convex function of firm value, therefore leading to risk-seeking managers.

\subsection{Liability-Based Incentive}

Although there has been a rigorous examination of executives' equity compensation in the literature, the exploration of liability-based compensation remains relatively limited after Jensen and Meckling (1976) first formulated a concept of debt-like compensation. Until recently, Bebchuk and Fried (2004) state that pension and other retirement benefits are considerably large in relation to executives' actual compensation. Sundaram and Yermack (2007) implement one of the first empirical research on debt-like compensations of large U.S. companies' CEOs. They find that when a CEO's incentive leverage (a ratio of liability-based compensation relative to equity-based compensation) exceeds the firm's leverage ratio, CEOs tend to manage firms more conservatively, such as investing on less risky projects, lowering the use of debt capital or choosing long-maturity debt, and trimming dividends payout. An event study by Wei and Yermack (2011) indicates that a wealth 
transfer from stockholders to debtholders is associated with the announcements of granting pension and deferred compensation to CEOs. Additional examinations of the impact of CEO pension on firm policies include White (2012), Anantharaman et al. (2014), and Cassell et al. (2012). In particular Cassell et al. (2012) find a negative relationship between pension compensation and the volatility of equity returns, financial leverage or $R \& D$ expenditures, but a positive relation between debt compensation and firm diversification or asset liquidity. Anantharaman et al. (2014) find that CEOs' pension incentive is associated with a lower cost of debt financing and fewer restrictive covenants. Moreover, White (2012) examines how pension incentive affects the dividend policy. Overall, studies suggest that pension incentives have a significant influence on discouraging risk taking behavior.

\subsection{Hypothesis Development}

As suggested by Sundaram and Yermack (2007), the nature of unsecured and unfunded pension liabilities held by CEOs makes them in line with outside creditors. In other words, CEOs with greater pension benefits are expected to display lower levels of risk-seeking behavior since they are exposed to similar default risk. From risk management literature a well-known benefit of hedging is that hedging smooths firm performance, resulting in lower volatility of net income and cash flows (Smith and Stulz 1985). The probability of bankruptcy or financial distress is considerably higher when a firm's earnings or cash flows are more volatile. As hedging smooths cash flows or/and net incomes, bankruptcy risk will be reduced. Smith and Stulz (1985) suggest that hedging reduces a firm's cash flow volatility and consequently lowers the likelihood of bankruptcy. As a result, we conjecture that firms granting the higher level of pension incentive to CEOs are more likely to engage in hedging activities. Our first hypothesis is formulated as:

Hypothesis 1 (H1). Pension incentive has a positive impact on corporate hedging activity.

Given that our first hypothesis reveals an important relationship between pension incentive and hedging behavior, there is another question that remains unclear, namely the interplay of pension incentive and governance on this relation. To disentangle the relation between corporate hedging and CEO pension incentive in the different context of governance, we propose our second hypothesis: Pension incentive is a part of the optimal contract that is designed to mitigate agency costs of debt (e.g., risk-shifting) and agency costs of equity (effort-shirking). Under this logic, we would expect CEOs with a larger amount of debt-like compensation relative to equity compensation (i.e., a higher CEO pension relative leverage) to be more active hedgers of the "priced" risk. Since corporate hedging is an outcome of an optimal compensation contract for CEOs, we anticipate that the predicted positive relation between hedging and executives' pension incentive should be observed in firms with strong corporate governance. Thus, our second hypothesis can be offered as:

Hypothesis 2 (H2). The positive relation between pension incentive and the hedging activity should be more pronounced for the firms with strong governance than those with poor governance.

To summarize, both hypotheses predict a positive relation between pension incentive and hedging. The theory of optimal contracting further suggests that a positive relation should be more significant for firms with strong corporate governance than for firms with weak governance. In contrast, however, an opposite view would predict that the positive relation between hedging and pension incentive should only hold for poorly governed firms where managers face fewer consequences from pursuing corporate policies that are mainly motivated for self-interests. In the empirical tests below, we first examine how pension incentive influences hedging, and further condition the relation on corporate governance to verify the $h$ of optimal contracting. 


\section{Sample Selection and Variable Construction}

\subsection{Sample Selection}

The information of executive pension is collected from the Standard and Poors' EXEUCOMP database. In 2006, the SEC issued a new rule on the proxy disclosure of executive compensation, requiring a detailed disclosure of pension and deferred compensation that are granted as a part of executive compensation. Accordingly, EXEUCOMP extends the coverage on this disclosure, which allows us to obtain top managers' pension compensation from 2006 and afterwards. Therefore, our initial sample includes all US firms whose CEOs are listed in EXEUCOMP from 2006 through 2015. Financial firms (with a SIC code of 6000 through 6999) and utility firms (with a SIC code of 4900 through 4999) are excluded as these firms are heavily regulated. We also eliminate observations with missing or negative total assets or negative common equity. Such criteria generate the initial sample of 1936 firms with 16,936 firm-years.

Following the literature (Doukas and Pantzalis 2003; Graham and Rogers 2002; Campello et al. 2011), we identify the multinational firms with ex ante exposure to currency risk if they report foreign assets, foreign sales, or foreign income in the COMPUSTAT Geographic Segment databases, or they disclose positive amounts of foreign currency adjustment, exchange rate effect, foreign income taxes, or deferred foreign taxes in the annual COMPUSTAT database. We identify an MNC sample of 49,557 firm-year observation associated with 8642 firms that have foreign operation activities from 2006 to $2015 .{ }^{1}$ Given the fact of the different coverage between COMPUSTAT and EXECUCOMP (EXECUCOMP mainly covers the large-cap firms), after merging two databases we obtain the final sample of 11,718 firm-year observations associated with 1625 firms that have foreign operation activities from 2006 to 2015.

We retrieved the information of firm hedging activities through conducing a textual search in 10-K filings compiled in the Securities and Exchange Commission (SEC) EDGAR database. Specifically, we performed the search based on a set of keywords including: currency derivative, currency swaps, currency forwards, currency futures, currency options, currency contract, currency forward contract, exchange forward, exchange future, exchange swap, exchange option, exchange contract, or forward exchange contract. For each keyword found, we review the context in which the keyword appears in the report to confirm the use of derivatives for hedging. We match the 10-K filing information with the financial data from COMPUSTAT by the identifier of Central Index Key (CIK).

\subsection{Measure of Active Management of Currency Risk}

Based on the above sample, we examine the firms' foreign currency risk management by examining their hedging strategy against the currency risk. To retrieve hedging data, we perform a keyword search for financial derivatives uses in 10-K filings compiled in the SEC EDGAR database. In this study, we focus on foreign currency derivatives. The foreign currency derivatives are most commonly used for hedging strategy by non-financial U.S. firms. Géczy et al. (1997) investigate the use of derivatives for a sample of Fortune 500 non-financial firms in 1993 and find that currency derivatives are used most frequently by corporation (52.1\%). For each type of derivative, we use a set of relevant key words as specified above for the corresponding currency derivative instruments. When a keyword is found, we review the context in which the keyword appears in the report to confirm the use of derivatives for hedging and to collect hedging information. We use two proxies from literature to describe corporate

1 We also follow Doukas and Pantzalis (2003) to consider the case that a firm might be subject to foreign currency risk due to the competitive environment. To do so, we include the keywords related to foreign currency risk and market risk in our textual searching program to read if firms explicitly state their foreign currency exposures in 10-K filings. We also perform the additional check by identifying MNCs by setting the ratios of foreign assets, foreign sales or foreign income greater than $10 \%$. This classification is based on the requirements of the Statement of Financial Accounting Standard No. 14 (Financial Accounting Standards Board 1976), which defines a firm as a multinational company if it reports foreign assets and foreign sales ratios of $10 \%$ or more. Both ways show the qualitatively consistent results. 
hedging activities. Following Nance et al. (1993), Géczy et al. (1997), and Chen and King (2014) we first use a dummy variable of hedging to represent if a firm implements hedging in a given year. The hedging dummy variable takes the value of one if a firm holds a hedging position using any types of foreign currency derivatives at the end of the fiscal year or has transactions involving one or more foreign currency derivatives for the purpose of hedging during that year, and zero otherwise. In addition, we use the notional amount of foreign currency derivatives in a given year to quantitatively capture the intensity of hedging activity.

\subsection{Measures of Pension Incentive}

As one of the main variables of interest for our study, we follow the literature to construct the measures of executive pension incentive. Sundaram and Yermack (2007) point out that retirement compensation and deferred compensation are two primary benefits generating CEO pension incentives. In the Execucomp database, the value of retirement compensation is defined to be the aggregate present (actuarial) value of the executive's accumulated benefits under the firm's pension plans, and deferred compensation is computed as the aggregate balance under the non-tax-qualified deferred compensation plan. Pension incentive motivates the executives to stand with the creditors to claim residual value during firm liquidations. Deferred compensation refers to the part of compensation which is deferred under the voluntary act of the executives to pay at pre-specified dates in the future. Such two types of compensation arrangements may work as the liability-like security to align CEO incentives with creditors and to induce less risky firm policies. Consequently, we expect a positive relation between hedging activity and executive pension incentive.

Although the equity-based components of CEO compensation have been documented in extant literature to cause risk-taking behavior, liability-based compensation is expected to lead to managerial risk aversion. Particularly, Jensen and Meckling (1976) conjecture that a compensation package with equal-weighted equity and debt instruments is superior to $100 \%$ equity compensation. In contrast, Edmans and Liu (2011) suggest granting executives equally weighted liability and equity compensation is typically inefficient. With the component of pension, the executives' wealth is aligned with both the incidence of bankruptcy and firm liquidation value, which makes them less incentive to transfer wealth from debtholders to stockholders and attenuates the stockholder-bondholder conflicts. However, on the other hand, executives paid with excessive pension compensation might engage in unnecessarily conservative policies and reallocate wealth from stockholders to debtholders. As a result, to quantitatively capture the incentive of liability-based compensation relative to equity-based compensation and also to consider the external influence of firm capital structure exposed on the executives, we form the two main proxies to gauge the relative magnitude of pension incentive. The first is relative pension leverage, which is defined as CEO pension leverage divided by firm leverage. We also adopt a dummy variable, which takes the value of one if the relative pension leverage is greater than one and zero otherwise, as a way to capture the possible non-linear relation between dominant liability-based incentives and managerial risk attitude. These measures are also suggested by Edmans and Liu (2011) and Wei and Yermack (2011). We speculate that firms with a higher relative pension leverage have a higher likelihood of hedging and a larger notional amount of hedging derivatives.

\subsection{Control Variables}

The motivations of corporate hedging have been well examined in the literature; thus, we follow the previous studies to incorporate those important drivers of hedging as control variables. Below we briefly discuss the motivation of including those control variables. We first control for CEO equity-based compensation, which is based on stocks and options granted to the executives: One is the change in stock price, which affects the value of stock holding and value of options, and the other is the volatility of stock return, which mainly affects the value of options. Guay (1999) highlights the difference between these two measures, with the former notated by delta and the latter by vega. More incentives from 
delta expose more firm risk to managers and cause them risk averse, while compensation with vega incentive helps offset the problem of underinvestment due to the risk aversion that arises from delta incentive. In addition, Rogers (2002) argues that it has more explicitly economic sense to measure the CEO risk-taking incentive per dollar of value-increasing incentives, namely, the ratio of vega to delta (vega/delta). We expect a negative relation between the ratio of vega/delta and hedging since a stronger risk-taking incentive from compensation makes executive more aggressive and are consequently less likely to hedge.

Smith and Stulz (1985) suggest that hedging reduces the volatility of corporate performance, resulting in a lower bankruptcy risk. The probability of bankruptcy or financial distress is considerably higher when a firm's leverage is higher, or when interest coverage or percentage of tangible assets is lower. Therefore, there is a negative relation between interest coverage or tangible assets and hedging, and a positive relation between leverage and hedging. Froot et al. (1993) theorize that hedging can curtail the underinvestment problem (Myers 1977) when a firm faces potential growth opportunities but suffers a high cost of external financing. Following Gay and Nam (1998), we use the correlation between cash flow and firm investment to gauge the underinvestment problem and expect a positive relation between this measure and hedging, indicating that firms with a severe underinvestment problem tend to hedge. In the case of a progressive (convex) tax schedule, marginal tax rate increases with taxable income. Hedging reduces the expected tax liability by smoothing taxable income. Therefore, a positive relation between tax benefit and hedging is predicted. We adopt two measures of tax benefit: a dummy variable indicating positive tax credit and a continuous variable of tax convexity, which measures the expected tax savings from a 5\% reduction in the volatility of taxable income (Graham and Smith 1999). Cash holdings are regarded as a natural mechanism to alleviate the negative impact of uncertainty. In addition, convertible bonds can be also used to reduce the agency cost of debt. As both are potential alternatives of hedging, we include them and expect a negative relation between these substitutes and hedging.

\subsection{Descriptive Statistics}

Our final sample contains 1625 firms and 11,718 firm-year observations. Table 1 provides the summary statistics of hedging behavior, pension incentive, equity incentive and control variables for this final sample. We find that in general hedging appears in 52\% of the firm-years and the notional amount of hedging position is on average USD 19.51 million, an equivalent of about $8.2 \%$ of total assets for the full sample of firm-year observations, and rises to USD 260.7 million. These results are consistent with the literature. For example, Campello et al. (2011) report that $50 \%$ of their sample firms use foreign currency derivative to hedge and the positions of derivatives account for about $7.5 \%$ of firm assets, respectively. As to the pension incentive variables, on average, CEOs are paid with USD 2.63 million of pension benefits. Such liability-based compensation constitutes $36 \%$ of CEOs' total compensation or $54 \%$ of equity-based compensation.

The variable of CEO pension relative leverage has a mean (median) value of $4.72(0.30)$ in our final sample. Less than half $(39 \%)$ of the firm-year observations have this variable greater than one. For equity incentive, the mean values of Delta incentive and Vega incentive are 0.14 and 0.01 , respectively. We also note that the ratio of Vega/Delta has an average value of 0.24 , suggesting that risk-taking incentive tied to stock volatility represents about a quarter of the value-increasing incentives driven by stock price. Our sample firms on average have a moderate leverage ratio of 0.18 and a healthy interest coverage ratio of 24.61. On average market-to-book ratio is 1.66 and the tangible assets ratio is $76 \%$. The correlation between cash flow and firm investments has a mean (median) value of 0.41 (0.48). In addition, the sample firms hold $18 \%$ assets in cash and $3 \%$ assets in convertible bond contracts. We also find that $56 \%$ sample firm-year observations have a positive tax credit and the average tax convexity is USD 2.13 million, both suggesting that the tax benefits associated with smoothing incomes are considerably attractive. Finally, about $71 \%$ of the board members are from out of the firms to serve as independent directors and 33\% firm stakes are held by the institutional blockholders. 
Table 1. Summary statistics.

\begin{tabular}{|c|c|c|c|c|c|c|}
\hline & $\mathbf{N}$ & Mean & Median & SD & P25 & P75 \\
\hline \multicolumn{7}{|l|}{ Pension Incentive } \\
\hline CEO Pension (USD M) & 11,718 & 2.63 & 0.00 & 7.59 & 0.00 & 0.80 \\
\hline CEO Pension/Equity Compensation & 11,221 & 0.54 & 0.03 & 1.36 & 0.00 & 0.46 \\
\hline CEO Pension Relative Leverage & 9488 & 7.72 & 0.30 & 31.69 & 0.00 & 2.76 \\
\hline Dummy (CEO Pension Relative Leverage $>1$ ) & 9488 & 0.39 & 0.00 & 0.49 & 0.00 & 1.00 \\
\hline Currency Hedging Intensity (Notional Amount, USD M) & 11,718 & 19.51 & 0.00 & 187.98 & 0.00 & 0.00 \\
\hline Currency Hedging Intensity (USD M, For Hedgers) & 6128 & 260.70 & 71.31 & 639.91 & 21.55 & 197.73 \\
\hline \multicolumn{7}{|l|}{ CEO-Equity Incentive } \\
\hline Delta Incentive & 11,718 & 0.14 & 0.06 & 0.23 & 0.03 & 0.18 \\
\hline Vega Incentive & 11,718 & 0.01 & 0.01 & 0.02 & 0.00 & 0.02 \\
\hline Leverage & 11,718 & 0.18 & 0.15 & 0.14 & 0.06 & 0.27 \\
\hline Market-to-book Ratio & 11,718 & 1.66 & 1.38 & 0.75 & 1.11 & 1.94 \\
\hline Interest Coverage & 11,718 & 24.61 & 8.43 & 42.74 & 3.84 & 20.51 \\
\hline Tangible Assets Ratio & 11,718 & 0.76 & 0.80 & 0.21 & 0.54 & 0.96 \\
\hline Corr(Cash Flow, Investment) & 11,718 & 0.41 & 0.48 & 0.42 & 0.15 & 0.76 \\
\hline Cash Holding & 11,718 & 0.18 & 0.10 & 0.21 & 0.03 & 0.24 \\
\hline Convertible Bonds Ratio & 11,718 & 0.03 & 0.00 & 0.06 & 0.00 & 0.00 \\
\hline Positive Tax Credit (Dummy) & 11,718 & 0.56 & 1.00 & 0.50 & 0.00 & 1.00 \\
\hline Tax Convexity (MUSD) & 11,718 & 2.13 & 1.72 & 1.67 & 0.70 & 3.40 \\
\hline Board Independence & 11,718 & 0.71 & 0.80 & 0.14 & 0.43 & 0.93 \\
\hline Institutional Blockholder Ownership & 11,718 & 0.33 & 0.30 & 0.08 & 0.15 & 0.57 \\
\hline
\end{tabular}

This table shows summary statistics of pension incentive variables, hedging variables, equity incentive variables, and firm-related variables for the sample of 11,718 firm-year observations from 2006 through 2015 with winsorization at the 1th and 99th percentiles. All variable definitions are reported in Appendix A.

Moreover, we present the Pearson correlation matrix of hedging activity and incentive variables in Table 2, which indicates a positive relation between hedging activity and CEO pension incentives. For example, CEO Pension Relative Leverage is significantly positive correlated with both of hedging measures, including hedging propensity (0.36) and hedging intensity (0.35). These relations suggest that greater pension incentives may lead to more hedging activities. In addition, Delta incentive and Vega incentive - these two equity-based incentives - are found to have a different correlation with hedging activity. Note that Delta incentive has an insignificant correlation with hedging, while Vega incentive has a significantly negative correlation with hedging, which is consistent with the literature of equity compensation that granting equity, particularly stock options to managers should, ceteris paribus, generate incentives to take more risks, or consequently hedge less.

Table 2. Correlations matrix between hedging and pension incentive.

\begin{tabular}{|c|c|c|c|c|c|c|c|c|c|c|}
\hline Variables & [1] & [2] & [3] & [4] & [5] & [6] & [7] & [8] & [9] & [10] \\
\hline Foreign Currency Hedging Propensity [1] & 1 & & & & & & & & & \\
\hline Foreign Currency Hedging Intensity [2] & $0.60 *$ & 1 & & & & & & & & \\
\hline CEO Pension (USD M) [3] & $0.32 *$ & $0.26 *$ & 1 & & & & & & & \\
\hline CEO Pension/Total Compensation [4] & $0.31 *$ & $0.26 *$ & $0.34 *$ & 1 & & & & & & \\
\hline CEO Pension/Equity Compensation [5] & $0.37 *$ & $0.31 *$ & 0.84 * & $0.75^{*}$ & 1 & & & & & \\
\hline Ln (CEO Pension Relative Leverage) [6] & $0.36^{*}$ & $0.35 *$ & $0.64 *$ & $0.65 *$ & $0.80 *$ & 1 & & & & \\
\hline Dummy (Pension Relative Leverage $>1$ ) [7] & $0.36 *$ & 0.35 * & $0.67 *$ & $0.66^{*}$ & $0.82 *$ & $0.88 *$ & 1 & & & \\
\hline Delta Incentive [8] & 0.04 & 0.03 & $0.20 *$ & $0.19 *$ & $0.26^{*}$ & $0.16^{*}$ & $0.18^{*}$ & 1 & & \\
\hline Vega Incentive [9] & $-0.07 *$ & $-0.07 *$ & -0.11 & $-0.05 *$ & $-0.10 *$ & -0.05 & $-0.06^{*}$ & $-0.06 *$ & 1 & \\
\hline Vega Incentive/Delta Incentive [10] & $-0.07 *$ & $-0.05 *$ & $-0.20 *$ & $-0.11 *$ & $-0.22 *$ & $-0.09 *$ & $-0.10 *$ & $-0.33 *$ & $-0.54 *$ & 1 \\
\hline
\end{tabular}

This table presents the Pearson correlation coefficients between hedging variables and CEO pension incentive for the final sample from 2006 through 2015. * denotes statistical significance under 5\% level. All variable definitions are reported in Appendix A. 


\section{Model Specification and Empirical Results}

\subsection{Baseline Model}

The primary purpose of this research is to investigate the influence of executive pension incentive on firms' active management of risk. Utilizing the final sample of multinational firms that are exposed to foreign currency risk, we first implement the baseline model regressions of hedging activity on a series of regressors, which contain the measures of pension incentives as the main independent variables, equity incentive variables, the proxies for other hedging drivers discussed in Section 3.4, and control for heterogeneity across industries and time. The baseline model is specified as follows:

$$
\begin{aligned}
\text { Hedge }_{i, t}= & \alpha+\beta * \text { PensionIncentive }_{i, t-1}+\gamma_{1} \text { EquityIncentive }_{i, t-1}+\gamma_{2} \text { Leverage }_{i, t-1}+\gamma_{3} \text { InterestCov }_{i, t-1} \\
& +\gamma_{4} \text { Tangible }_{i, t-1}+\gamma_{5}{\text { Market } / \text { book }_{i, t-1}+\gamma_{6} \text { Corr }\left(C F, \text { Investment }_{i, t-1}+\gamma_{7} \text { TaxDummy }_{i, t-1}\right.} \\
& \left.+\gamma_{8} \text { TaxCovexity }_{i, t-1}+\gamma_{9} \text { CashHolding }_{i, t-1}+\gamma_{10} \text { CovertibleBond }_{i, t-1}+\gamma_{11} \text { Ln }_{\text {TotalAssets }}\right)_{i, t-1} \\
& +\sum_{k=1}^{47} \text { Industry }_{k}+\sum_{t=1}^{10} \text { Year }_{t}+\varepsilon_{i, t}
\end{aligned}
$$

where hedging, the dependent variable, is measured by the dummy variable of hedging or the continuous variable of hedging intensity. The measures of pension incentives include the logarithm of CEO pension benefits in dollar amount, the ratio of CEO pension benefits to $\mathrm{CEO}$ total compensation, the ratio of $\mathrm{CEO}$ pension benefits to $\mathrm{CEO}$ equity compensation. Additionally, following the literature, the continuous variable of CEO pension relative leverage and the dummy variable of CEO pension relative leverage greater than one are constructed. ${ }^{2}$ As to CEO equity-based compensation, the incentives of stock and option compensation are gauged by Delta incentive, Vega incentive, and a ratio of Vega incentive to Delta incentive.

To analyze the impact of pension incentives on the hedging adoption, we first perform a Probit model analysis by regressing the dummy variable of hedging on the explanatory variables specified in Equation (1). The results are reported in Panel A of Table 3. To facilitate the interpretation of regression results, we report the incremental effects on the probability of implementing hedging strategy for a one standard deviation change in continuous explanatory variables. However, the incremental effects for the logarithmic variables (i.e., the logarithm of CEO pension relative leverage) or the incremental effects for the dichotomous variables (i.e., the dummy variable of CEO pension relative leverage greater than 1 or the dummy variable of positive tax credit) follow the traditional pattern. ${ }^{3}$ Z-values based on robust standard errors are reported in parentheses to test whether the coefficients are equal to zero. Consistent with the theoretical predictions provided on the sign column, we first observe strong evidence across models that CEO pension incentives have a significantly positive influence on the decision of currency hedging. From Model 1 through Model 3, we look at the effect of pension incentives by directly examining the dollar amount of CEO pension incentive, the proportion of pension benefits to total compensation, and the proportion of pension benefits to equity-based compensation. The coefficients of pension incentive in these models all show significant and positive relations with corporate hedging decision. For example, a one-standard-deviation increase in the overall pension benefits in dollar amount leads to an increase of $2.2 \%$ in hedging probability. Similarly, a one-standard-deviation increase in pension proportion in CEO total compensation (equity

2 We also test the alternative measures, such as the CEO pension relative leverage and the squared CEO pension relative leverage, and we find general consistent results. However, considering the potential skewness in the variable of CEO pension relative leverage, we adopt the logarithm form of CEO pension relative leverage or use the conversion to a dummy indicator of CEO pension relative leverage.

3 Specifically, for each of continuous explanatory variables we multiply the coefficients of the regressions by the standard deviations of each independent variable, while for the logarithmic variables and the dichotomous variables we directly report the coefficient of estimation. 
compensation) increases the hedging probability by $6.5 \%$ (4.8\%). More importantly, the effect of CEO pension incentives on hedging probability is economically meaningful. In Model 4 the continuous measure of $\mathrm{CEO}$ pension relative leverage has a positive and significant coefficient $(0.006)$, suggesting that a percentage increase in CEO pension relative leverage leads to about $1.6 \%$ increase in the likelihood of hedging. In Model 5, we find when the CEO pension relative leverage is greater than one, that is, when CEO's wealth "leverage" is greater than firm's capital "leverage", the probability of corporate hedging is higher by $20.9 \%$.

Table 3. Baseline Models of Impact of Pension Incentive on Hedging.

\begin{tabular}{|c|c|c|c|c|c|c|}
\hline \multicolumn{7}{|c|}{ Panel A: Probit Model of Hedging Propensity } \\
\hline & Sign & [1] & [2] & [3] & [4] & [5] \\
\hline CEO Pension (USD M)) & + & $\begin{array}{l}0.022 * * \\
(2.545)\end{array}$ & & & & \\
\hline CEO Pension/Total Compensation & + & & $\begin{array}{c}0.065^{* * *} \\
(2.628)\end{array}$ & & & \\
\hline CEO Pension/Equity Compensation & + & & & $\begin{array}{c}0.048^{* * *} \\
(3.064)\end{array}$ & & \\
\hline Ln (CEO Pension Relative Leverage) & + & & & & $\begin{array}{c}0.016^{* *} \\
(2.313)\end{array}$ & \\
\hline Dummy (CEO Pension Relative Leverage $>1$ ) & + & & & & & $\begin{array}{c}0.209 * * * \\
(3.352)\end{array}$ \\
\hline Delta Incentive & + & $\begin{array}{c}1.241 \\
(0.891)\end{array}$ & $\begin{array}{c}0.477 \\
(0.341)\end{array}$ & $\begin{array}{c}0.865 \\
(0.620)\end{array}$ & $\begin{array}{c}0.834 \\
(0.596)\end{array}$ & $\begin{array}{c}0.731 \\
(0.523)\end{array}$ \\
\hline Vega Incentive & - & $\begin{array}{c}-0.273^{* *} \\
(-2.259)\end{array}$ & $\begin{array}{c}-0.195 \\
(-1.602)\end{array}$ & $\begin{array}{c}-0.376^{* * *} \\
(-3.133)\end{array}$ & $\begin{array}{l}-0.216^{*} \\
(-1.762)\end{array}$ & $\begin{array}{l}-0.228 * \\
(-1.862)\end{array}$ \\
\hline Leverage & + & $\begin{array}{c}1.066^{* * *} \\
(4.947)\end{array}$ & $\begin{array}{c}0.949 * * * \\
(4.417)\end{array}$ & $\begin{array}{c}0.908^{* * *} \\
(4.242)\end{array}$ & $\begin{array}{c}1.359 * * * \\
(6.180)\end{array}$ & $\begin{array}{c}1.336^{* * *} \\
(6.092)\end{array}$ \\
\hline Interest Coverage & - & $\begin{array}{c}-0.002^{* * *} \\
(-3.455)\end{array}$ & $\begin{array}{c}-0.002^{* * *} \\
(-3.283)\end{array}$ & $\begin{array}{c}-0.002^{* * *} \\
(-3.567)\end{array}$ & $\begin{array}{c}-0.002^{* * *} \\
(-4.149)\end{array}$ & $\begin{array}{c}-0.002 \text { *** } \\
(-3.756)\end{array}$ \\
\hline Tangible Assets Ratio & - & $\begin{array}{c}-0.362^{* * *} \\
(-2.630)\end{array}$ & $\begin{array}{c}-0.388^{* * *} \\
(-2.808)\end{array}$ & $\begin{array}{l}-0.310 * * \\
(-2.260)\end{array}$ & $\begin{array}{l}-0.353^{* *} \\
(-2.567)\end{array}$ & $\begin{array}{c}-0.367^{* * *} \\
(-2.666)\end{array}$ \\
\hline Market to Book & + & $\begin{array}{c}0.029 \\
(0.757)\end{array}$ & $\begin{array}{c}0.035 \\
(0.922)\end{array}$ & $\begin{array}{c}0.037 \\
(0.986)\end{array}$ & $\begin{array}{c}0.011 \\
(0.297)\end{array}$ & $\begin{array}{c}0.013 \\
(0.353)\end{array}$ \\
\hline Corr (CF, Investment) & - & $\begin{array}{c}-0.134 * * \\
(-2.413)\end{array}$ & $\begin{array}{c}-0.132 * * \\
(-2.379)\end{array}$ & $\begin{array}{l}-0.127 * * \\
(-2.308)\end{array}$ & $\begin{array}{c}-0.133^{* *} \\
(-2.394)\end{array}$ & $\begin{array}{c}-0.130 * * \\
(-2.350)\end{array}$ \\
\hline Positive Tax Credit (Dummy) & + & $\begin{array}{c}0.130 * * * \\
(3.150)\end{array}$ & $\begin{array}{c}0.137^{* * *} \\
(3.307)\end{array}$ & $\begin{array}{c}0.139 * * * \\
(3.382)\end{array}$ & $\begin{array}{c}0.129 * * * \\
(3.123)\end{array}$ & $\begin{array}{c}0.128^{* * *} \\
(3.091)\end{array}$ \\
\hline Tax Convexity & + & $\begin{array}{c}-0.033^{* *} \\
(-2.447)\end{array}$ & $\begin{array}{c}-0.028^{* *} \\
(-2.114)\end{array}$ & $\begin{array}{c}-0.030 \text { ** } \\
(-2.232)\end{array}$ & $\begin{array}{c}-0.029^{* *} \\
(-2.177)\end{array}$ & $\begin{array}{l}-0.030^{* *} \\
(-2.213)\end{array}$ \\
\hline Cash Holding & - & $\begin{array}{c}-0.456^{* * *} \\
(-3.292)\end{array}$ & $\begin{array}{c}-0.442^{* * *} \\
(-3.205)\end{array}$ & $\begin{array}{c}-0.509^{* * *} \\
(-3.713)\end{array}$ & $\begin{array}{c}-0.463^{* * *} \\
(-3.346)\end{array}$ & $\begin{array}{c}-0.424 * * * \\
(-3.062)\end{array}$ \\
\hline Convertibles Bonds & - & $\begin{array}{c}-1.790^{* * *} \\
(-4.433)\end{array}$ & $\begin{array}{c}-1.504^{* * *} \\
(-3.728)\end{array}$ & $\begin{array}{c}-1.502 * * * \\
(-3.739)\end{array}$ & $\begin{array}{c}-1.516^{* * *} \\
(-3.767)\end{array}$ & $\begin{array}{c}-1.520 * * * \\
(-3.775)\end{array}$ \\
\hline Log (Total Assets) & + & $\begin{array}{l}0.348^{* * *} \\
(20.278)\end{array}$ & $\begin{array}{l}0.334^{* * *} \\
(19.159)\end{array}$ & $\begin{array}{l}0.358^{* * *} \\
(20.733)\end{array}$ & $\begin{array}{l}0.346^{* * *} \\
(20.102)\end{array}$ & $\begin{array}{l}0.345^{* * *} \\
(19.973)\end{array}$ \\
\hline Intercept & & $\begin{array}{c}-2.508^{* * *} \\
(-7.130)\end{array}$ & $\begin{array}{c}-2.506^{* * *} \\
(-7.072)\end{array}$ & $\begin{array}{c}-2.676^{* * *} \\
(-7.570)\end{array}$ & $\begin{array}{c}-2.632 * * * \\
(-7.484)\end{array}$ & $\begin{array}{c}-2.635^{* * *} \\
(-7.450)\end{array}$ \\
\hline Industry and Year Fixed Effect & & Yes & Yes & Yes & Yes & Yes \\
\hline Number of Observations & & 11,718 & 11,718 & 11,221 & 9488 & 9488 \\
\hline Pseudo $\mathrm{R}^{2}$ & & 0.369 & 0.369 & 0.371 & 0.393 & 0.391 \\
\hline \multicolumn{7}{|c|}{ Panel B: Tobit Model of Hedging Intensity } \\
\hline & Sign & [1] & [2] & [3] & [4] & [5] \\
\hline CEO Pension (USD M) & + & $\begin{array}{c}0.009 * * \\
(2.238)\end{array}$ & & & & \\
\hline CEO Pension/Total Compensation & + & & $\begin{array}{l}0.035 * \\
(1.695)\end{array}$ & & & \\
\hline CEO Pension/Equity Compensation & + & & & $\begin{array}{c}0.027^{* *} \\
(2.501)\end{array}$ & & \\
\hline Ln (CEO Pension Relative Leverage) & + & & & & $\begin{array}{l}0.004 * \\
(1.690)\end{array}$ & \\
\hline Dummy (CEO Pension Relative Leverage $>1$ ) & + & & & & & $\begin{array}{c}0.018^{* * *} \\
(2.919)\end{array}$ \\
\hline
\end{tabular}


Table 3. Cont.

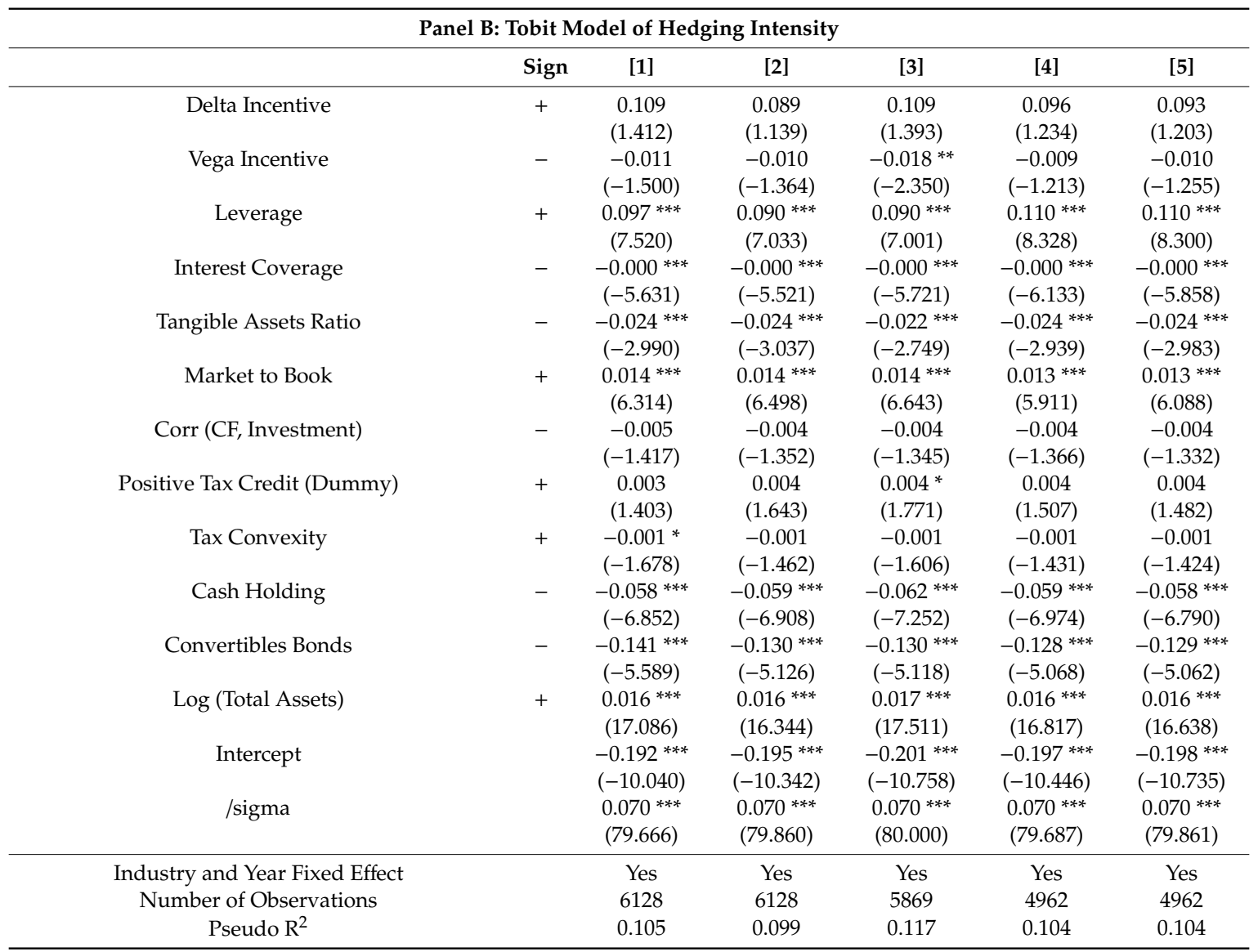

This table shows the results of baseline model regressions of hedging activity for the sample of 3492 firm-years from 2006 through 2010. Panel A reports the effects on the probability of hedging from Probit model for a one standard deviation change in continuous explanatory variables (or for a change from zero to one in dummy explanatory variable). In Panel B we apply Tobit model to regress the total notional amount of hedging positions scaled by book value of total assets on the set of explanatory variables. We control for industry effects by using the Fama-French 48-industry classification and control for time effects by using year dummies. The robust standard errors are used to calculate Z-Statistics (Probit model) or T-Statistics (Tobit model) that are reported in parentheses below estimates. $*, * *$ and ${ }^{* * *}$ denote significance at the $10 \%, 5 \%$ and $1 \%$ levels, respectively.

For firm-related variables, the results are generally consistent with the literature. Leverage has the positive impact on hedging, and both interest coverage and tangible assets are negatively related with hedging. We also find a significantly negative association between hedging and the correlation of cash flow and investments, suggesting that firms with a lower degree of matching between cash flows and investment needs tend to hedge more. Furthermore, we find evidence to support the potential tax benefits of hedging. For example, the dummy variable of positive tax credit has positive and significant effect on hedging. Lastly, we find that cash holding and convertible bonds are both negatively associated with hedging, indicating that they may serve as possible substitutes for hedging.

Liability-based incentive urges executives' inclination to take risk-reduced investment, i.e., more likely to hedge and increase the magnitude of hedging activity. To detect how pension incentive affects the intensity of hedging, we turn to an investigation by applying the continuous measure of hedging activity. Specifically, we replace hedging dummy variable in Equation (1) with the notional amount of hedging positions scaled by the book value of total assets. We keep the same set of explanatory variables. Given the nature of non-negative notional amount of hedging position, we adopt Tobit regressions for our baseline models. The results are shown in Panel B of Table 3. Across the models, we find a significantly positive relation between the notional amount of hedging and all measures of pension incentives. The positive relations between pension incentive and hedging notional amount to 
total assets ratio are detected from Models 1 through 4. For example, we observe from Model 1 that firms increase about USD 81 million (=0.009 *USD 8987 million) when pension compensation increases one-standard-derivation or equivalently USD 7.59 million. In addition, the coefficient (0.004) in Model 4 shows that for a one percent increase in CEO pension relative leverage, the hedging position rises by 40 basis points of total assets $(0.4 \%)$, and in other words, firms on average increase their hedging positions by USD 35.95 million ( $=0.04 \% *$ USD 8987 million). Finally, this significant and positive relation also holds in Models 5, when CEOs' wealth leverage is greater than firms' leverage, the ratio of hedging position to total assets is higher by $1.8 \%$. Considering that the average hedging notional amount to total assets ratio is $2.9 \%$ (=USD 260.70/USD 8987), the change of the CEO pension relative leverage from less than or equal to one to greater than one boosts the hedging intensity by more than $60 \%(1.8 \% / 2.9 \%=62 \%)$. Overall, the results of baseline models provide supportive evidence to our first hypothesis.

\subsection{Alternative Models to Control for Equity-Based Incentives}

While the focus of this research is not about equity-based incentive, it may be arguable that equity-based incentive is designed differently for the sample firms that are more/less likely to do currency risk management. From our baseline models, we find that Vega incentive is negatively associated with hedging decision, but an insignificant impact of Delta incentive on hedging decision is also observed. Although the results of equity incentives seem mixed from the theoretical predictions, these discordant results are also reported in the literature. For instance, Guay (1999) illustrates that shareholders should consider the slope and convexity of the relation between executives' compensation and firm performance, where slope (Delta) refers to the sensitivity of executives' compensation to stock price and convexity (Vega) refers to the sensitivity of executives' compensation to stock return volatility. As a result, granting equity compensation to executives should, ceteris paribus, generate incentives to take more risks, or equivalently hedge less. Knopf et al. (2002) provide the evidence to support the positive association between hedging and the sensitivity of a manager's equity wealth to stock price and the negative association between hedging and the sensitivity of a manager's equity wealth to stock return volatility. Rajgopal and Shevlin (2002) report a significantly negative relation between risk-taking incentives (Vega) and commodity hedging for a sample of gas and oil firms.

But in a similar setting, Rogers (2002) only find weak evidence of Delta and Vega incentives which affect the hedging decision. Accordingly, Rogers (2002) proposes economic interpretation of the ratio of Vega to delta should be more intuitive because it measures the CEO risk-taking incentive per dollar of value-increasing incentives from option and stock holdings that delta and Vega measure managerial motivation from "value-creating" and "risk-taking" incentives, respectively. On the other hand, Lewellen (2006) demonstrates that the "moneyness" of stock options has different impacts on managerial risk attitude. In particular, those in-the-money options discourage risk-taking. Meanwhile, as emphasized by Carpenter (2000) equity compensation does not necessarily result in more risk-taking behavior because it makes executives' wealth more vulnerable to stock price fluctuation. Hirshleifer and Suh (1992) also discuss the side effect of equity compensation, which encourages executives to work hard but also affects their attitude toward project risks, ending up with less risk-taking. Gerakos (2010) provides some evidence that executives granted with more pension benefits are paid less on other dimensions of compensation.

To ensure that the results of the baseline model are not vulnerable to the potential inconsistent impact of equity-based incentive, we perform the alternative models to recognize the evidence from Carpenter (2000). The results of the alternative models are shown in Table 4 and report the regressions by adopting the ratio of Vega incentive to Delta incentive. As expected, we find the significant and negative coefficients of this variable across the models. For example, the ratio of Vega incentive to Delta incentive are negatively associated with both hedging propensity in Model 3 of Panel A (-0.226) and hedging intensity in Model 3 of Panel B (-0.028). With this new control variable in Table 4, the coefficients of pension incentive measures keep positive. Notably, the effect of pension incentive 
on hedging propensity and on hedging intensity are also statistically significant, consistent with the finding in Table 3. To this end, the alternative models help confirm that hedging activity is plausibly affected by the executive pension incentive.

Table 4. Alternative Models of Impact of Pension Incentive on Hedging.

\begin{tabular}{|c|c|c|c|c|c|c|}
\hline \multicolumn{7}{|c|}{ Panel A: Probit Model of Hedging Propensity } \\
\hline & Sign & [1] & [2] & [3] & [4] & [5] \\
\hline CEO Pension (USD M) & + & $\begin{array}{l}0.024^{* *} \\
(2.533)\end{array}$ & & & & \\
\hline CEO Pension/Total Compensation (\%) & + & & $\begin{array}{c}0.066 \text { ** } \\
(2.612)\end{array}$ & & & \\
\hline CEO Pension/Equity Compensation (\%) & + & & & $\begin{array}{c}0.047^{* * *} \\
(3.012)\end{array}$ & & \\
\hline Ln (CEO Pension Relative Leverage) & + & & & & $\begin{array}{c}0.017^{* *} \\
(2.256)\end{array}$ & \\
\hline Dummy (CEO Pension Relative Leverage $>1$ ) & + & & & & & $\begin{array}{c}0.204^{* * *} \\
(3.218)\end{array}$ \\
\hline Vega Incentive/Delta Incentive & - & $\begin{array}{c}-0.154^{* *} \\
(-2.256)\end{array}$ & $\begin{array}{c}-0.135^{* *} \\
(-1.975)\end{array}$ & $\begin{array}{c}-0.226 * * * \\
(-2.809)\end{array}$ & $\begin{array}{l}-0.156^{* *} \\
(-2.278)\end{array}$ & $\begin{array}{l}-0.157^{* *} \\
(-2.291)\end{array}$ \\
\hline Firm-related Characteristics & & Yes & Yes & Yes & Yes & Yes \\
\hline Industry and Year Fixed Effect & & Yes & Yes & Yes & Yes & Yes \\
\hline Number of Observations & & 11,718 & 11,718 & 11,221 & 9488 & 9488 \\
\hline Pseudo $R^{2}$ & & 0.368 & 0.368 & 0.370 & 0.392 & 0.391 \\
\hline \multicolumn{7}{|c|}{ Panel B: Tobit Model of Hedging Intensity } \\
\hline & Sign & [1] & [2] & [3] & [4] & [5] \\
\hline CEO Pension (USD M) & + & $\begin{array}{l}0.009 * * \\
(2.401)\end{array}$ & & & & \\
\hline CEO Pension/Total Compensation (\%) & + & & $\begin{array}{l}0.038^{*} \\
(1.732)\end{array}$ & & & \\
\hline CEO Pension/Equity Compensation (\%) & + & & & $\begin{array}{l}0.030^{* *} \\
(2.503)\end{array}$ & & \\
\hline Ln (CEO Pension Relative Leverage) & + & & & & $\begin{array}{l}0.005^{*} \\
(1.740)\end{array}$ & \\
\hline Dummy (CEO Pension Relative Leverage $>1$ ) & + & & & & & $\begin{array}{c}0.019^{* * *} \\
(3.172)\end{array}$ \\
\hline Vega Incentive/Delta Incentive & - & $\begin{array}{c}-0.021 \\
(-1.496)\end{array}$ & $\begin{array}{c}-0.020 \\
(-1.618)\end{array}$ & $\begin{array}{c}-0.028^{* *} \\
(-2.222)\end{array}$ & $\begin{array}{c}-0.026^{* *} \\
(-2.061)\end{array}$ & $\begin{array}{c}-0.030^{* *} \\
(-2.395)\end{array}$ \\
\hline Firm-related Characteristics & & Yes & Yes & Yes & Yes & Yes \\
\hline Industry and Year Fixed Effect & & Yes & Yes & Yes & Yes & Yes \\
\hline Number of Observations & & 6128 & 6128 & 5869 & 4962 & 4962 \\
\hline Pseudo $R^{2}$ & & 0.099 & 0.102 & 0.105 & 0.099 & 0.117 \\
\hline
\end{tabular}

This table shows the results of the alternative models of pension incentive on hedging activity by recognizing a different measure of equity incentives (the ratio of Vega incentive relative to Delta incentive). Panel A reports the effects on the probability of hedging from Probit model for a one standard deviation change in continuous explanatory variables (or for a change from zero to one in dummy explanatory variable). In Panel B we apply Tobit model to regress the total notional amount of hedging positions scaled by book value of total assets on the set of explanatory variables. We control for industry effects by using the Fama-French 48-industry classification and control for time effects by using year dummies. The robust standard errors are used to calculate Z-Statistics (Probit model) or T-Statistics (Tobit model) that are reported in parentheses below estimates. ${ }^{*}, * *$ and ${ }^{* * *}$ denote significance at the $10 \%, 5 \%$ and $1 \%$ levels, respectively.

\subsection{Robustness Checks for Endogeneity}

In this section, we tend to identify the causal drive of the pension incentive to the hedging activity. As in most research in business, endogeneity may cause a concern in this study. While, by and large, the relation between pension incentive and hedging is well supported by theoretical work, it is relatively challenging to capture the causal effect because compensation contracts and hedging practices can be determined by unobservable firm-related and other factors. 
We employ the approach of instrumental variables (IV) regression, where two instruments (firm age and CEO age) are used for each of the pension incentive measures in regressions. ${ }^{4}$ In particular, treated as endogenous variable, pension incentive is regressed on a set of all other explanatory variables plus firm age and CEO age as instruments in the first stage. Predicted values of pension incentive are computed from the first-stage regression and used in the second-stage regression as specified in Equation (1).

We report the results in Table 5. In Model 5 of Panel A, as the dependent variable (hedging dummy) and the endogenous independent variable (the dummy variable of CEO pension relative leverage greater than one) are both dichotomous variables, we apply the Bivariate Probit model. Specifically, we simultaneously estimate a system in which the first and second stage regressions are both Probit models (Greene 2004). For other models of the hedging dummy regressions, we apply the IV-Probit model in which the first stage is an OLS (Ordinary Least Squares) model and the second stage is a Probit model. For the models in Panel B where the dependent variable is hedging notional amount scaled by the firm size (a continuous nonnegative variable), we apply IV-Tobit model as a regular IV regressions with truncated continuous dependent variable, namely, the first stage is an OLS model and the second stage is a Tobit model. Panel B of Table 5 reports the second stage results of IV regressions on hedging dummy and hedging notional amount, respectively. Consistent with our conjecture, the positive relation between hedging and pension incentive remain robust after controlling for potential endogeneity. Meanwhile, we find that the impact of equity-based incentives also shows evidence consistent with theoretical predications. For example, in Model 5 of Panel A (the hedging dummy regression), the coefficient of Vega incentive relative to Delta incentive is negative and significant the $5 \%$ level. In the regressions of hedging notional amount, the coefficient of this variable is found negative and significant at the $1 \%$ level in Models 5 of Panel B.

Table 5. Instrumental variables regressions.

\begin{tabular}{|c|c|c|c|c|c|c|}
\hline \multicolumn{7}{|c|}{ Panel A: Instrumental Variable Regression of Debt Incentives on Hedging Propensity } \\
\hline & Sign & [1] & [2] & [3] & [4] & [5] \\
\hline CEO Pension (USD M) & + & $\begin{array}{c}1.410 * * * \\
(3.463)\end{array}$ & & & & \\
\hline CEO Pension/Total Compensation (\%) & + & & $\begin{array}{c}2.386^{* * *} \\
(3.951)\end{array}$ & & & \\
\hline CEO Pension/Equity Compensation (\%) & + & & & $\begin{array}{c}3.015^{* * *} \\
(3.984)\end{array}$ & & \\
\hline Ln (CEO Pension Relative Leverage) & + & & & & $\begin{array}{c}0.251^{* * *} \\
(3.224)\end{array}$ & \\
\hline Dummy (CEO Pension Relative Leverage $>1$ ) & + & & & & & $\begin{array}{c}0.959 * * * \\
(3.542)\end{array}$ \\
\hline Vega Incentive/Delta Incentive & - & $\begin{array}{l}-1.028 * * \\
(-2.233)\end{array}$ & $\begin{array}{c}-0.201 \\
(-0.954)\end{array}$ & $\begin{array}{l}-0.083 * * \\
(-2.086)\end{array}$ & $\begin{array}{c}-0.225 \\
(-0.895)\end{array}$ & $\begin{array}{c}-0.142^{* *} \\
(-2.067)\end{array}$ \\
\hline Leverage & + & $\begin{array}{c}1.843^{* * *} \\
(4.911)\end{array}$ & $\begin{array}{c}0.940 * * * \\
(4.296)\end{array}$ & $\begin{array}{c}0.828^{* * *} \\
(3.768)\end{array}$ & $\begin{array}{c}2.093 * * * \\
(4.884)\end{array}$ & $\begin{array}{c}1.939 * * * \\
(5.366)\end{array}$ \\
\hline Interest Coverage & - & $\begin{array}{c}-0.001 \\
(-0.728)\end{array}$ & $\begin{array}{l}-0.001 * * \\
(-2.422)\end{array}$ & $\begin{array}{c}-0.002^{* * *} \\
(-2.921)\end{array}$ & $\begin{array}{c}-0.002^{* * *} \\
(-4.239)\end{array}$ & $\begin{array}{c}-0.002^{* * *} \\
(-3.374)\end{array}$ \\
\hline Tangible Assets Ratio & - & $\begin{array}{c}-0.833^{* * *} \\
(-3.553)\end{array}$ & $\begin{array}{c}-0.521 * * * \\
(-3.431)\end{array}$ & $\begin{array}{c}-0.388^{* * *} \\
(-2.727)\end{array}$ & $\begin{array}{c}-0.478^{* * *} \\
(-3.110)\end{array}$ & $\begin{array}{c}-0.484^{* * *} \\
(-3.215)\end{array}$ \\
\hline Market to Book & + & $\begin{array}{c}-0.039 \\
(-0.750)\end{array}$ & $\begin{array}{c}0.028 \\
(0.715)\end{array}$ & $\begin{array}{c}0.038 \\
(0.999)\end{array}$ & $\begin{array}{c}-0.031 \\
(-0.701)\end{array}$ & $\begin{array}{c}-0.017 \\
(-0.415)\end{array}$ \\
\hline Corr (CF, Investment) & - & $\begin{array}{l}-0.130 * \\
(-1.875)\end{array}$ & $\begin{array}{c}-0.127 * * \\
(-2.255)\end{array}$ & $\begin{array}{l}-0.110 * \\
(-1.954)\end{array}$ & $\begin{array}{l}-0.129 * * \\
(-2.272)\end{array}$ & $\begin{array}{l}-0.125^{* *} \\
(-2.215)\end{array}$ \\
\hline Positive Tax Credit (Dummy) & + & $\begin{array}{c}0.071 \\
(1.282)\end{array}$ & $\begin{array}{c}0.139 * * * \\
(3.308)\end{array}$ & $\begin{array}{c}0.164^{* * *} \\
(3.830)\end{array}$ & $\begin{array}{c}0.123 * * * \\
(2.906)\end{array}$ & $\begin{array}{c}0.120 * * * \\
(2.857)\end{array}$ \\
\hline
\end{tabular}

4 We recheck the results by trying the lagged variable approach, with which the endogenous variable of pension incentive is lagged to help in mitigating the potential bias of endogeneity. We observe the positive relation between hedging activity and pension incentive unchanged. 
Table 5. Cont.

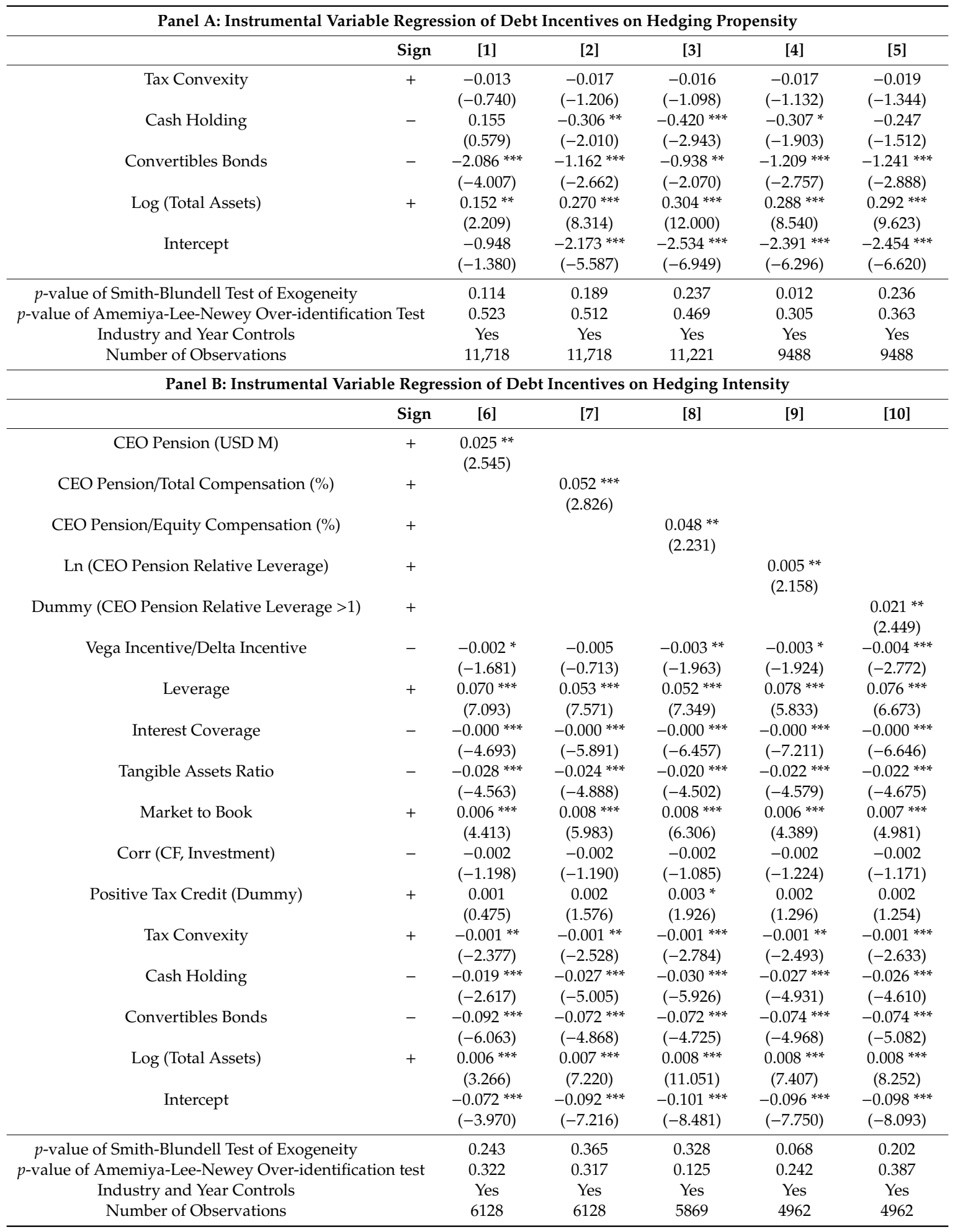

This table reports the results of the robustness checks based instrumental variables (IV) models. The dependent variables are hedging dummy in Panel A and are hedging intensity (the ratio of total notional amount of hedging positions scaled by the book value of total assets) in Panel B. The two-stage regressions with a Probit model in the second stage are applied on Panel A and the two-stage regressions with a Tobit model in the second stage are applied on Panel B, respectively. We control for industry effects by using the Fama-French 48-industry classification and control for time effects by using year dummies. The robust standard errors are used in all models in Panel A to calculate Z-Statistics or T-Statistics that are reported in parentheses below estimates. ${ }^{*},{ }^{* *}$ and ${ }^{* * *}$ denote significance at the $10 \%, 5 \%$ and $1 \%$ levels, respectively. 
Roberts and Whited (2013) suggest that the IV regression model is only as good as the choice of instrumental variables. We select the instruments by considering both its relevance with pension incentives and irrelevance with hedging. More specifically, the relevance rule requires a non-zero correlation between an instrument and the endogenous variable of pension incentive, and the irrelevance rule indicates that the selected instrument must not be correlated with the unobserved determinants of hedging. Existing literature on pension benefits suggests that CEO age and firm age are closely related to the granting of retirement plans (Liu et al. 2014; Cassell et al. 2012; Sundaram and Yermack 2007). The firm age is used as one of instrumental variables due to the business life-cycle reason. Firms usually do not offer pension or other fringe benefit plans when they start in business, and gradually adopt them afterwards. Brown and Medoff (2003) document that the firms that have been in business longer are more likely to implement pension plans. With the consideration of little conclusive theory in classical economics for the connection between hedging activity and biological age, CEO age is used as another variable in the set of instruments. However, we are aware of some evidence in the recent literature that reports the impact of executives' age on corporate polices. For example, Serfling (2014) suggests that younger CEOs generally have a more aggressive leadership style. Jenter and Lewellen (2015) and Yim (2013) show that younger CEOs are more likely to engage in risky acquisitions. Croci et al. (2017) find a high likelihood of being a hedger from senior CEOs. When biological age connects to executives' psychological or physiological situation, the CEOs' age may not be able to introduce exogenous variations to capture the causal impact of pension incentive on firms' hedging policy. ${ }^{5}$

But to be more prudent, we use the econometric methods to test the verification of IV model and instruments. We employ the Smith-Blundell test of exogeneity to test the null hypothesis that there is no serious endogeneity in the model, and the Amemiya-Lee-Newey over-identification test to test the null hypothesis that there is no over-identification problem. Across the models, we find that the null hypothesis of Smith-Blundell test of exogeneity cannot be rejected in all Models except Model 4 for the hedging propensity and hedging intensity, indicating that a problem of endogeneity is not extensively present. Meanwhile, from models 1 through 4 for both the hedging propensity and hedging intensity regressions, the p-value in the Amemiya-Lee-Newey over-identification test is much greater than $10 \%$, indicating that the instruments are chosen appropriately and there is no over-identification problem in our models. To summarize, the robustness checks confirm that the positive impact of pension incentive on hedging activities detected in baseline models is unlikely to be driven by the endogeneity issue.

\subsection{The Role of Pension Incentive in Different Governance Environment}

From the above empirical analyses a significant and positive relation between hedging and pension incentive has been documented in baseline and robustness models, but another important question, which relates to a considerable debate regarding the nature of incentive design as aforementioned, is how this positive relation varies in the different situations of corporate governance. As a component of compensation contract, pension incentive itself is closely associated with governance mechanism. Lee and Tang (2011) document that CEO pension benefits are associated with corporate governance. They find that entrenched managers, proxied by a small board, CEO duality, and protection from anti-takeover provisions, are more likely to obtain higher compensation of pension benefits. Halford and Qiu (2012) test whether firms that are likely to face more severe agency problems of debt

5 With this caveat in mind, we seek the alternative instruments by trying the federal and state personal tax rates (Anantharaman et al. 2014; Kim and Lu 2011), as one can reasonably assume that those highest-paid CEOs would have different preference towards the compensation packages when they are subject to the different personal income tax brackets. In addition, we also utilize a regulatory reform, Pension Protection Act in 2006, which attempts to strengthen the pension system, protects retirement accounts and makes pension benefits more attractive. As the legislation provides greater incentives to firms and employees in investing in pension plans, this exogenous change of law should have no implicit impacts on the hedging decision. Although the tests by using the above alternative sets of instruments show the qualitatively consistent results, we acknowledge that the potential issue of endogeneity cannot be entirely resolved given the lack of perfect instruments, and therefore the causality results based on the IV models should be interpreted with caution. 
provide more debt incentives. Inconsistent with the agency theory's prediction they find evidence that firms with lower default risk use more pension plans, and little evidence to support the hypothesis that pension incentive is used to alleviate the agency costs of debt.

In Section 2, our second hypothesis (H2) predicts the different relations between corporate hedging and CEO liability-based compensation which are conditional upon the strength of corporate governance. Recall that our first hypothesis proposes a positive relation between hedging and pension incentive. However, the optimal contracting hypothesis predicts that the positive relation should be more significant for firms with strong corporate governance than for firms with weak governance. Thus, in this section we test how the influence of pension incentive on hedging is contingent on the mechanism of corporate governance. In Table 6, we present the regressions of three baseline models but in the subsamples categorized by the median value of board independence.

Following the same steps, we report the incremental effect on the probability of hedging for a one-standard-deviation change in the continuous explanatory variables (or for a change from zero to one for the dummy explanatory variables). Furthermore, we apply the Chow test to examine the difference in coefficients between the two subsamples. Panel A reports the results for the hedging propensity regressions. In particular, the influence of pension incentive on hedging is more pronounced for the firms in the above-median group than in the below-median group ( 0.069 vs. 0.04 in Model 1 and Model 2). In other words, the effect of pension incentives on hedging is more prominent for firms with strong shareholder power. The differences are also economically significant based on the predicted probabilities. Specifically, Model 5 and Model 3 show that when CEOs' wealth leverage is greater than firms' leverage, it will cause a $44 \%(=0.287 / 0.650)$ rise in predicated probability of hedging for the firms in the above-median group of independent board directors, but only a $16 \%(=0.124 / 0.783)$ rise for the firms in the below-median group of independent board directors. Panel B of Table 6 reports the results based on the notional value of hedging, further confirming the finding.

Similarly, we conduct the subsample comparison by splitting firms into groups with the median value of blockholder ownership and report the results in Table 7. In Models 1 and 2 of Panel A, we find that a one-standard-deviation increase in pension incentive in firms with higher blockholder ownership will increase $7.3 \%$ of hedging probability, more than double the increase $(2.8 \%)$ in the subsample with lower blockholder ownership. A similar difference with statistical significance is also found in Panel B of Table 7. For example, the coefficient of the dummy variable of CEO pension relative leverage greater than 1 is substantially larger in the subsample with low blockholder ownership than that in the subsample with high blockholder ownership (0.028 vs. 0.016 in Model 5 and Model 6) with significance at the $5 \%$ level. As a result, the above evidence lends strong support for the optimal contracting hypothesis (our second hypothesis). The pension incentive is governed to expose more influence on executives' decisions, and this risk-reducing function is induced more when firms have strong governance, but does not fully perform in the case of weak governance. 
Table 6. The influence of pension incentive on hedging by board independence.

\begin{tabular}{|c|c|c|c|c|c|c|c|c|c|c|}
\hline \multicolumn{11}{|c|}{ Panel A: The Influence of Pensive Incentive on Hedging Propensity by Board Independence } \\
\hline & Sign & (> Median) & ( $<$ Median) & Diff & (> Median) & (< Median) & Diff & (> Median) & (< Median) & Diff \\
\hline & & [1] & [2] & Chow test & [3] & [4] & Chow test & [5] & [6] & Chow test \\
\hline CEO Pension/Equity Compensation (\%) & + & $\begin{array}{c}0.069 * * * \\
(5.249)\end{array}$ & $\begin{array}{c}0.040 \\
(1.048)\end{array}$ & $\begin{array}{c}0.029 * * * \\
(2.907)\end{array}$ & & & & & & \\
\hline Ln (CEO Pension Relative Leverage) & + & & & & $\begin{array}{c}0.018^{* *} \\
(2.440)\end{array}$ & $\begin{array}{l}0.008 * \\
(1.893)\end{array}$ & $\begin{array}{l}0.009 \text { * } \\
(1.736)\end{array}$ & & & \\
\hline Dummy (CEO Pension Relative Leverage $>1$ ) & + & & & & & & & $\begin{array}{c}0.287^{* * *} \\
(3.700)\end{array}$ & $\begin{array}{c}0.124 \\
(1.303)\end{array}$ & $\begin{array}{l}0.163^{* *} \\
(2.302)\end{array}$ \\
\hline Firm-related Characteristics & & Yes & Yes & & Yes & Yes & & Yes & Yes & \\
\hline Industry and Year Controls & & Yes & Yes & & Yes & Yes & & Yes & Yes & \\
\hline Number of Observations & & 5455 & 5455 & & 2216 & 2217 & & 2216 & 2217 & \\
\hline Pseudo $\mathrm{R}^{2}$ & & 0.435 & 0.422 & & 0.472 & 0.465 & & 0.433 & 0.439 & \\
\hline \multicolumn{11}{|c|}{ Panel B: The Influence of Pensive Incentive on Hedging Intensity by Board Independence } \\
\hline & Sign & (> Median) & (< Median) & Diff & (> Median) & (< Median) & Diff & (> Median) & ( $<$ Median) & Diff \\
\hline & & [1] & [2] & Chow test & [3] & [4] & Chow test & [5] & [6] & Chow test \\
\hline CEO Pension/Equity Compensation (\%) & + & $\begin{array}{c}0.039 * * * \\
(3.187)\end{array}$ & $\begin{array}{c}0.019 \\
(0.716)\end{array}$ & $\begin{array}{c}0.020 * * * \\
(3.661)\end{array}$ & & & & & & \\
\hline Ln (CEO Pension Relative Leverage) & + & & & & $\begin{array}{c}0.005^{* * *} \\
(3.875)\end{array}$ & $\begin{array}{c}0.003 \\
(1.218)\end{array}$ & $\begin{array}{c}0.002 * * * \\
(2.586)\end{array}$ & & & \\
\hline Firm-related Characteristics & & Yes & Yes & & Yes & Yes & & Yes & Yes & \\
\hline Industry and Year Controls & & Yes & Yes & & Yes & Yes & & Yes & Yes & \\
\hline Number of Observations & & 2867 & 2867 & & 2413 & 2414 & & 2413 & 2414 & \\
\hline Pseudo $\mathrm{R}^{2}$ & & 0.186 & 0.181 & & 0.135 & 0.133 & & 0.138 & 0.138 & \\
\hline
\end{tabular}

This table reports the regressions for the subsamples categorized by board independence. The Probit Model is applied in Panel A where the dependent variable is hedging dummy, and Tobit models are used in Panel B where the dependent variable is the ratio of total notional amount of hedging positions scaled by the book value of total assets. We control for industry effects by using the Fama-French 48-industry and control for time effects by using year dummies. The robust standard errors are to calculate Z-Statistics or T-Statistics reported in parentheses below estimates. ${ }^{*}, * *$ and ${ }^{* * *}$ denote significance at the $10 \%, 5 \%$ and $1 \%$ levels, respectively. 
Table 7. The influence of pension incentive on hedging by blockholder ownership.

\begin{tabular}{|c|c|c|c|c|c|c|c|c|c|c|}
\hline \multicolumn{11}{|c|}{ Panel A: The Influence of Pensive Incentive on Hedging Propensity by Blockholder Ownership. } \\
\hline & Sign & (> Median) & ( $<$ Median) & Diff & (> Median) & (<Median) & Diff & (> Median) & (< Median) & Diff \\
\hline & & [1] & [2] & Chow test & [3] & [4] & Chow test & [5] & [6] & Chow test \\
\hline CEO Pension/Equity Compensation (\%) & + & $\begin{array}{c}0.073^{* * *} \\
(4.875)\end{array}$ & $\begin{array}{c}0.028 \\
(1.568)\end{array}$ & $\begin{array}{c}0.045^{* * *} \\
(2.788)\end{array}$ & & & & & & \\
\hline Ln (CEO Pension Relative Leverage) & + & & & & $\begin{array}{c}0.020 * * \\
(2.495)\end{array}$ & $\begin{array}{l}0.014^{*} \\
(1.949)\end{array}$ & $\begin{array}{c}0.006 \\
(1.614)\end{array}$ & & & \\
\hline Dummy (CEO Pension Relative Leverage $>1$ ) & + & & & & & & & $\begin{array}{c}0.251^{* * *} \\
(2.202)\end{array}$ & $\begin{array}{c}0.132 \\
(1.072)\end{array}$ & $\begin{array}{l}0.119^{*} \\
(1.893)\end{array}$ \\
\hline Firm-related Characteristics & & Yes & Yes & & Yes & Yes & & Yes & Yes & \\
\hline Industry and Year Controls & & Yes & Yes & & Yes & Yes & & Yes & Yes & \\
\hline Number of Observations & & 5455 & 5455 & & 2216 & 2217 & & 2216 & 2217 & \\
\hline Pseudo $\mathrm{R}^{2}$ & & 0.431 & 0.430 & & 0.464 & 0.468 & & 0.419 & 0.418 & \\
\hline \multicolumn{11}{|c|}{ Panel B: The Influence of Pensive Incentive on Hedging Intensity by Blockholder Ownership } \\
\hline & Sign & (> Median) & ( $<$ Median) & Diff & (> Median) & (<Median) & Diff & (> Median) & (< Median) & Diff \\
\hline & & [1] & [2] & Chow test & [3] & [4] & Chow test & [5] & [6] & Chow test \\
\hline CEO Pension/Equity Compensation (\%) & + & $\begin{array}{c}0.043^{* * *} \\
(2.667)\end{array}$ & $\begin{array}{c}0.021 \\
(0.762)\end{array}$ & $\begin{array}{c}0.021 * * \\
(2.348)\end{array}$ & & & & & & \\
\hline Ln (CEO Pension Relative Leverage) & + & & & & $\begin{array}{c}0.007^{* * *} \\
(2.605)\end{array}$ & $\begin{array}{l}0.002 * \\
(1.690)\end{array}$ & $\begin{array}{c}0.004^{* *} \\
(2.351)\end{array}$ & & & \\
\hline Firm-related Characteristics & & Yes & Yes & & Yes & Yes & & Yes & Yes & \\
\hline Industry and Year Controls & & Yes & Yes & & Yes & Yes & & Yes & Yes & \\
\hline Number of Observations & & 2867 & 2867 & & 2414 & 2413 & & 2414 & 2413 & \\
\hline Pseudo $R^{2}$ & & 0.187 & 0.181 & & 0.134 & 0.134 & & 0.138 & 0.137 & \\
\hline
\end{tabular}

This table reports the regressions for the subsamples categorized by blockholder ownership. The Probit Model is applied in Panel A where the dependent variable is hedging dummy, and Tobit models are used in Panel B where the dependent variable is the ratio of total notional amount of hedging positions scaled by the book value of total assets. We control for industry effects by using the Fama-French 48-industry and control for time effects by using year dummies. The robust standard errors are to calculate Z-Statistics or T-Statistics reported in parentheses below estimates. ${ }^{*}, * *$ and ${ }^{* * *}$ denote significance at the $10 \%, 5 \%$ and $1 \%$ levels, respectively. 


\section{The Influence of Pension Incentive on Value of Corporate Hedging}

Tan and Young (2016) show that executives motivated by the long-term incentive pay, such as retirement plans may engage in behaviors unfavorable to shareholders. To provide a novel insight into the role of pension incentive in terms of value creation, we adopt Faulkender and Wang's (2006) methodology to assess the marginal value of hedging as a function of CEO pension incentives. We first treat hedging motivated by pension incentive as a beneficial driver to shareholders. Therefore, in addition to the firm characteristics specified in Faulkender and Wang (2006), we include the change of hedging activity in the regression model to quantify the value of hedging:

$$
\begin{aligned}
r_{i, t}-R_{i, t}^{B}= & \gamma_{0}+\beta * \Delta \operatorname{Hedge}_{i, t}+\gamma_{1} L_{i, t}+\gamma_{2} \frac{\Delta C_{i, t}}{M_{i, t-1}}+\gamma_{3} \frac{\Delta E_{i, t}}{M_{i, t-1}}+\gamma_{4} \frac{\Delta N A_{i, t}}{M_{i, t-1}}+\gamma_{5} \frac{\Delta R D_{i, t}}{M_{i, t-1}}+\gamma_{6} \frac{\Delta I_{i, t}}{M_{i, t-1}} \\
& +\gamma_{7} \frac{\Delta D_{i, t}}{M_{i, t-1}}+\gamma_{8} \frac{N F_{i, t}}{M_{i, t-1}}+\sum_{t=1}^{10} \gamma_{e a r_{t}}+\varepsilon_{i, t}
\end{aligned}
$$

where the dependent variable $r_{i, t}$ is the annual excess equity return calculated from a firm i's stock return over year $t-1$ to year $t$, net of $R_{r, t}^{B}$, the return of Fama and French (1993) size and book-to-market matched portfolio from year $t-1$ to year $t . \Delta X_{i, t}$ is the notation for the one-year change of variable $X$ for firm $i$ over year $t-1$ to year $t$, i.e., $X_{t}-X_{t-1} ; \Delta$ Hedge, ${ }_{t}$ represents the hedging propensity $(H P)$ or change of hedging intensity $(H I) . M_{i, t}$ is market value of equity at time $t ; C_{i, t}$ is cash plus marketable securities; $E_{i, t}$ is earnings before extraordinary items plus interest, deferred tax credits, and investment tax credits; $N A_{i, t}$ is total assets minus cash holdings; $R D_{i, t}$ is research and development expense (which is set to zero if missing); $I_{i, t}$ is interest expense; $D_{i, t}$ is common dividends; $N F_{i, t}$ is total equity issuances minus repurchases plus debt issuances minus debt redemption; $L_{i, t}$ is the ratio of long-term debt plus debt in current liabilities divided by the market value of assets at time $t$. The regression results of Equation (2) are reported in Table 8. We use three measures of pension incentive to separate the sample.

\begin{tabular}{|c|c|c|c|c|c|c|c|}
\hline \multicolumn{8}{|c|}{ Panel A: The Value of Hedging Propensity by Pension Incentive } \\
\hline & \multirow{3}{*}{$\begin{array}{c}\text { Full } \\
\text { Sample }\end{array}$} & \multicolumn{2}{|c|}{$\begin{array}{l}\text { CEO Pension/Equity } \\
\text { Compensation (\%) }\end{array}$} & \multicolumn{2}{|c|}{$\begin{array}{c}\text { CEO Pension Relative } \\
\text { Leverage }\end{array}$} & \multicolumn{2}{|c|}{$\begin{array}{c}\text { CEO Pension Relative } \\
\text { Leverage }\end{array}$} \\
\hline & & $\begin{array}{l}\text { (High } \\
\text { Group) }\end{array}$ & $\begin{array}{l}\text { (Low } \\
\text { Group) }\end{array}$ & $\begin{array}{l}\text { (High } \\
\text { Group) }\end{array}$ & $\begin{array}{l}\text { (Low } \\
\text { Group) }\end{array}$ & $>1$ & $<1$ \\
\hline & & [1] & [2] & [3] & [4] & [5] & [6] \\
\hline$H P_{i, t}$ & $\begin{array}{c}1.015^{*} \\
1.682\end{array}$ & $\begin{array}{l}1.039 * * \\
(1.973)\end{array}$ & $\begin{array}{c}1.007 \\
(0.390)\end{array}$ & $\begin{array}{l}1.022 * \\
(1.724)\end{array}$ & $\begin{array}{c}1.018 \\
(1.018)\end{array}$ & $\begin{array}{l}1.025 * * \\
(2.367)\end{array}$ & $\begin{array}{c}1.017 \\
(0.953)\end{array}$ \\
\hline$L_{i, t}$ & $\begin{array}{l}-0.796 * * * \\
(-10.227)\end{array}$ & $\begin{array}{c}-0.661^{* * *} \\
(-7.162)\end{array}$ & $\begin{array}{l}-0.765^{* * *} \\
(-10.165)\end{array}$ & $\begin{array}{l}-0.841^{* * *} \\
(-10.503)\end{array}$ & $\begin{array}{c}-0.607^{* * *} \\
(-7.618)\end{array}$ & $\begin{array}{l}-0.726^{* * *} \\
(-8.798)\end{array}$ & $\begin{array}{c}-0.746^{* * *} \\
(-9.344)\end{array}$ \\
\hline$\Delta C_{i, t} / M_{i, t-1}$ & $\begin{array}{l}0.949 * * * \\
(6.106)\end{array}$ & $\begin{array}{l}1.052 * * * \\
(7.064)\end{array}$ & $\begin{array}{c}0.847 * * * \\
(6.827)\end{array}$ & $\begin{array}{l}0.974^{* * *} \\
(7.270)\end{array}$ & $\begin{array}{l}0.900 * * * \\
(6.725)\end{array}$ & $\begin{array}{l}1.026^{* * *} \\
(7.523)\end{array}$ & $\begin{array}{l}0.850 * * * \\
(6.470)\end{array}$ \\
\hline$\Delta E_{i, t} / M_{i, t-1}$ & $\begin{array}{l}0.865^{* * *} \\
(9.872)\end{array}$ & $\begin{array}{l}0.904^{* * *} \\
(8.540)\end{array}$ & $\begin{array}{l}0.935^{* * *} \\
(11.097)\end{array}$ & $\begin{array}{l}0.904^{* * *} \\
(10.382)\end{array}$ & $\begin{array}{l}0.961 * * * \\
(9.746)\end{array}$ & $\begin{array}{c}0.802 * * * \\
(9.098)\end{array}$ & $\begin{array}{l}1.106^{* * *} \\
(11.430)\end{array}$ \\
\hline$\Delta N A_{i, t} / M_{i, t-1}$ & $\begin{array}{c}-0.001 \\
(-0.023)\end{array}$ & $\begin{array}{c}0.007 \\
(0.105)\end{array}$ & $\begin{array}{l}-0.081 * \\
(-1.758)\end{array}$ & $\begin{array}{c}-0.076 \\
(-1.566)\end{array}$ & $\begin{array}{c}-0.018 \\
(-0.329)\end{array}$ & $\begin{array}{c}-0.026 \\
(-0.526)\end{array}$ & $\begin{array}{l}-0.110 * * \\
(-2.029)\end{array}$ \\
\hline$\Delta R D_{i, t} / M_{i, t-1}$ & $\begin{array}{c}0.301 \\
(0.184)\end{array}$ & $\begin{array}{c}3.247 \\
(1.416)\end{array}$ & $\begin{array}{l}-2.040 \\
(-1.102)\end{array}$ & $\begin{array}{c}3.161 \\
(1.502)\end{array}$ & $\begin{array}{c}-2.744 \\
(-1.385)\end{array}$ & $\begin{array}{c}2.641 \\
(1.219)\end{array}$ & $\begin{array}{c}-1.847 \\
(-0.952)\end{array}$ \\
\hline$\Delta I_{i, t} / M_{i, t-1}$ & $\begin{array}{c}-0.019 \\
(-0.994)\end{array}$ & $\begin{array}{c}-1.087 \\
(-0.612)\end{array}$ & $\begin{array}{l}-0.920 \\
(-0.755)\end{array}$ & $\begin{array}{c}1.937 \\
(1.436)\end{array}$ & $\begin{array}{c}-3.842^{* * *} \\
(-2.666)\end{array}$ & $\begin{array}{c}-1.291 \\
(-0.926)\end{array}$ & $\begin{array}{l}-0.849 \\
(-0.606)\end{array}$ \\
\hline$\Delta D_{i, t} / M_{i, t-1}$ & $\begin{array}{l}3.053 * \\
(1.787)\end{array}$ & $\begin{array}{c}2.649 \\
(0.611)\end{array}$ & $\begin{array}{c}4.122 \\
(0.877)\end{array}$ & $\begin{array}{c}-0.013 \\
(-0.003)\end{array}$ & $\begin{array}{l}9.081 * \\
(1.811)\end{array}$ & $\begin{array}{c}-0.058 \\
(-0.014)\end{array}$ & $\begin{array}{c}7.085 \\
(1.402)\end{array}$ \\
\hline$N F_{i, t} / M_{i, t-1}$ & $\begin{array}{c}0.135^{* * *} \\
(4.719)\end{array}$ & $\begin{array}{c}0.098^{* * *} \\
(3.678)\end{array}$ & $\begin{array}{c}0.129 * * * \\
(6.575)\end{array}$ & $\begin{array}{c}0.137 * * * \\
(6.319)\end{array}$ & $\begin{array}{c}0.092 * * * \\
(4.150)\end{array}$ & $\begin{array}{c}0.094^{* * *} \\
(4.270)\end{array}$ & $\begin{array}{c}0.137^{* * *} \\
(6.257)\end{array}$ \\
\hline Intercept & $\begin{array}{l}0.169 * * \\
(2.373)\end{array}$ & $\begin{array}{l}0.316 * * \\
(2.072)\end{array}$ & $\begin{array}{c}0.224 \\
(0.783)\end{array}$ & $\begin{array}{c}0.046 \\
(0.245)\end{array}$ & $\begin{array}{c}0.037 \\
(0.129)\end{array}$ & $\begin{array}{l}0.336 * \\
(1.765)\end{array}$ & $\begin{array}{c}0.149 \\
(0.523)\end{array}$ \\
\hline Year Controls & Yes & Yes & Yes & Yes & Yes & Yes & Yes \\
\hline $\mathrm{N}$ of Obs. & 11,718 & 5610 & 5611 & 4744 & 4744 & 3710 & 5778 \\
\hline Adjusted $R^{2}$ & 0.153 & 0.200 & 0.264 & 0.270 & 0.211 & 0.233 & 0.250 \\
\hline
\end{tabular}

Table 8. The impact of pension incentives on the value of hedging. 
Table 8. Cont.

\begin{tabular}{|c|c|c|c|c|c|c|c|}
\hline \multicolumn{8}{|c|}{ Panel B: The Value of Hedging Intensity by Pension Incentive } \\
\hline & \multirow{3}{*}{$\begin{array}{c}\text { Full } \\
\text { Sample }\end{array}$} & \multicolumn{2}{|c|}{$\begin{array}{l}\text { CEO Pension/Equity } \\
\text { Compensation }(\%)\end{array}$} & \multicolumn{2}{|c|}{$\begin{array}{c}\text { CEO Pension Relative } \\
\text { Leverage }\end{array}$} & \multicolumn{2}{|c|}{$\begin{array}{c}\text { CEO Pension Relative } \\
\text { Leverage }\end{array}$} \\
\hline & & $\begin{array}{l}\text { (High } \\
\text { Group) }\end{array}$ & $\begin{array}{l}\text { (Low } \\
\text { Group) }\end{array}$ & $\begin{array}{l}\text { (High } \\
\text { Group) }\end{array}$ & $\begin{array}{c}\text { (Low } \\
\text { Group) }\end{array}$ & $>1$ & $<1$ \\
\hline & & [1] & [2] & [3] & [4] & [5] & [6] \\
\hline \multirow[t]{2}{*}{$H I_{i, t-1} / M_{i, t-1}$} & 0.312 & $0.374 *$ & $0.291 *$ & $0.286^{*}$ & 0.370 & $0.326^{*}$ & $0.289 *$ \\
\hline & 1.518 & $(1.921)$ & (1.789) & $(1.852)$ & $(0.932)$ & $(1.936)$ & $(1.831)$ \\
\hline \multirow{2}{*}{$\Delta H I_{i, t} / M_{i, t-1}$} & -0.033 & 0.694 & -0.169 & -0.234 & 0.730 & -0.092 & 0.065 \\
\hline & $(-1.343)$ & $(0.924)$ & $(-0.216)$ & $(-0.337)$ & $(0.841)$ & $(-0.137)$ & $(0.072)$ \\
\hline \multirow[t]{2}{*}{$\left(H I_{i, t-1} / M_{i, t-1}\right)^{*}\left(\Delta H i_{i, t} / M_{i, t-1}\right)$} & $0.114 *$ & $0.204^{* *}$ & $0.059 *$ & $0.143^{* *}$ & -0.013 & $0.141^{* * *}$ & 0.129 \\
\hline & $(1.873)$ & $(2.328)$ & (1.934) & $(2.413)$ & $(-0.079)$ & $(2.890)$ & $(0.750)$ \\
\hline \multirow[t]{2}{*}{$L_{i, t}$} & $-0.811^{* * *}$ & $-0.764^{* * *}$ & $-0.850^{* * *}$ & $-0.939 * * *$ & $-0.684^{* * *}$ & $-0.834^{* * *}$ & $-0.800^{* * *}$ \\
\hline & $(-9.091)$ & $(-8.200)$ & $(-11.313)$ & $(-11.503)$ & $(-8.602)$ & $(-9.984)$ & $(-9.983)$ \\
\hline \multirow[t]{2}{*}{$\Delta C_{i, t} / M_{i, t-1}$} & $1.126^{* * *}$ & $1.045^{* * *}$ & $0.822 * * *$ & $0.962 * * *$ & $0.889 * * *$ & $1.018^{* * *}$ & $0.836^{* * *}$ \\
\hline & $(7.253)$ & $(7.087)$ & $(6.676)$ & $(7.248)$ & $(6.698)$ & $(7.558)$ & $(6.393)$ \\
\hline \multirow[t]{2}{*}{$\Delta E_{i, t} / M_{i, t-1}$} & $0.937^{* * *}$ & $0.877^{* * *}$ & $0.899^{* * *}$ & $0.861^{* * *}$ & $0.942 * * *$ & $0.770^{* * *}$ & $1.071^{* * *}$ \\
\hline & (8.303) & $(8.368)$ & $(10.697)$ & $(9.906)$ & $(9.647)$ & $(8.827)$ & (11.058) \\
\hline \multirow[t]{2}{*}{$\Delta N A_{i, t} / M_{i, t-1}$} & -0.043 & 0.024 & -0.067 & -0.048 & -0.017 & 0.008 & $-0.108 * *$ \\
\hline & $(-1.174)$ & $(0.392)$ & $(-1.473)$ & $(-0.984)$ & $(-0.307)$ & $(0.172)$ & $(-2.013)$ \\
\hline \multirow[t]{2}{*}{$\Delta R D_{i, t} / M_{i, t-1}$} & 1.602 & 3.403 & -1.694 & 2.871 & -1.966 & 2.781 & -1.371 \\
\hline & (1.518) & $(1.501)$ & $(-0.923)$ & (1.377) & $(-1.000)$ & $(1.301)$ & $(-0.710)$ \\
\hline \multirow[t]{2}{*}{$\Delta I_{i, t} / M_{i, t-1}$} & -0.658 & -0.395 & -0.511 & $2.607^{*}$ & $-3.293 * *$ & -0.954 & -0.275 \\
\hline & $(-0.593)$ & $(-0.224)$ & $(-0.422)$ & $(1.942)$ & $(-2.301)$ & $(-0.692)$ & $(-0.196)$ \\
\hline \multirow{2}{*}{$\Delta D_{i, t} / M_{i, t-1}$} & $0.165 * *$ & 4.493 & 6.099 & 2.232 & $9.893 * *$ & 1.866 & $8.906 *$ \\
\hline & $(2.059)$ & $(1.051)$ & $(1.305)$ & $(0.547)$ & $(1.996)$ & $(0.465)$ & $(1.770)$ \\
\hline \multirow[t]{2}{*}{$N F_{i, t} / M_{i, t-1}$} & $2.353 * *$ & $0.069 * *$ & $0.111^{* * *}$ & $0.114^{* * *}$ & $0.076^{* * *}$ & $0.073^{* * *}$ & $0.118^{* * *}$ \\
\hline & $(2.324)$ & $(2.557)$ & $(5.599)$ & $(5.194)$ & $(3.425)$ & $(3.297)$ & $(5.282)$ \\
\hline \multirow[t]{2}{*}{ Intercept } & 0.278 & $0.388^{* *}$ & 0.183 & 0.188 & 0.062 & 0.218 & 0.172 \\
\hline & $(0.497)$ & $(2.571)$ & $(0.645)$ & $(0.989)$ & $(0.219)$ & (1.151) & $(0.610)$ \\
\hline Year Controls & Yes & Yes & Yes & Yes & Yes & Yes & Yes \\
\hline $\mathrm{N}$ of Obs. & 6128 & 2935 & 2934 & 2481 & 2481 & 1940 & 3022 \\
\hline Adjusted $\mathrm{R}^{2}$ & 0.175 & 0.201 & 0.255 & 0.260 & 0.210 & 0.234 & 0.237 \\
\hline
\end{tabular}

This table presents the OLS regressions of excess stock returns on CEO pension incentive and the changes in firm characteristics, including the explanatory variables from Faulkender and Wang (2006) specification augmented with the measures of pension incentive, hedging variables, and governance variable. Panel A examines the propensity of hedging $(H P)$ and Panel B examines the intensity of hedging $(H I)$. In all panels the dependent variable is the annual excess equity return calculated from a firm $i$ 's stock return over year $t-1$ to year $t, r_{i, t}$, net of $R_{r, t}^{B}$, the return of Fama and French (1993) size and book-to-market matched portfolio from year $t-1$ to year $t$. $\Delta X_{i, t}$ is the notation for the one-year change of variable $X$ for firm $i$ over year $t-1$ to year $t$, i.e., $X_{t}-X_{t-1} ; H I_{i, t}$ is hedging principal (dollar amount of total notional value of derivatives) at time $t$, and $\Delta H I_{i, t}=H I_{i, t}-H I_{i, t-1} ; M_{i, t}$ is market value of equity at time $t ; C_{i, t}$ is cash plus marketable securities; $E_{i, t}$ is earnings before extraordinary items plus interest, deferred tax credits, and investment tax credits; $N A_{i, t}$ is total assets minus cash holdings; $R D_{i, t}$ is research and development expense; $I_{i, t}$ is interest expense; $D_{i, t}$ is common dividends; $N F_{i, t}$ is total equity issuances minus repurchases plus debt issuances minus debt redemption; $L_{i, t}$ is the ratio of long-term debt plus debt in current liabilities divided by the market value of assets at time $t$. The robust standard errors are to calculate T-Statistics reported in parentheses below estimates. ${ }^{*}, *$ and ${ }^{* * *}$ denote significance at the $10 \%, 5 \%$ and $1 \%$ levels, respectively.

Across the groups, we observe that the coefficients on the variables used in Faulkender and Wang (2006) are generally consistent with the literature. For example, cash and earnings are positively related to excess shareholder return, while leverage is negatively related to excess equity return. Considering that the dependent variable is excess equity return, the coefficient of explanatory variables measures the additional value accrued to the equity holder for one unit change of the explanatory variables. The coefficients of hedging propensity $\left(H P_{i, t}\right)$ and hedging intensity $\left(H_{i, t}\right)$ mean the additional value flowing to shareholder per one dollar investment in hedging position. Particularly, Panel A shows the incremental value contributed by hedging adoption to the shareholders. We find the value creation of hedging is more significant when pension incentive is higher. This indicates that pension incentive functions an effective mechanism in motivating executives to implement active risk management to create firm value. In Panel B, the existing hedging 
position $\left(N I_{i, t-1} / M_{i, t-1}\right)$, incremental hedging amount $\left(\Delta N I_{i, t} / M_{i, t-1}\right)$, and the interaction term of them are included. We find that the interaction term has a significant and positive impact on firm value. For example, the result in Model 1 shows that one dollar investment in existing hedging position brings USD 0.374 to shareholders and one dollar increase in hedging position creates an additional value of USD 0.204. In contrast, when pension incentive is in the lower level (Model 2), the additional value created by the hedging investment is only USD 0.059 per dollar of investment. This distinct difference suggests that the pension incentive promotes a firm's hedging strategy and also strengthens the value creation of hedging for shareholders.

Given the above finding as to how hedging creates value for shareholders, we advance further to consider the interplay of pension incentives and governance mechanisms. In particular, we augment the model specified in Equation (2) by adding measures of pension incentive and governance. For pension incentives, we construct a dummy variable, $P I$, for each of the pension incentive measures. Specifically, $P I$ takes the value of one when CEO Pension/Equity is greater than the median value of this variable, and takes the value of one when CEO Pension Relative Leverage is above the median value or greater than one, respectively. In addition, we construct the indictors of strong governance, a dummy variable that takes the value of one when Board Independence is greater than the median value, and zero otherwise. ${ }^{6}$ The regression model to examine the value of hedging with the consideration of pension incentive and governance is specified below in Equation (3):

$$
\begin{aligned}
r_{i, t}-R_{i, t}^{B}= & \beta_{1} * \text { Hedge }_{i, t}+\beta_{2} * P I_{i, t}+\beta_{3} * \operatorname{Gov}_{>p 50, i, t} * P I_{i, t} * \text { Hedge }_{i, t}+\beta_{4} * \operatorname{Gov}_{<p 50, i, t} * P I_{i, t} * \text { Hedge }_{i, t} \\
& +\gamma_{1} L_{i, t}+\gamma_{2} \frac{\Delta C_{i, t}}{M_{i, t-1}}+\gamma_{3} \frac{\Delta E_{i, t}}{M_{i, t-1}}+\gamma_{4} \frac{\Delta N A_{i, t}}{M_{i, t-1}}+\gamma_{5} \frac{\Delta R D_{i, t}}{M_{i, t-1}}+\gamma_{6} \frac{\Delta I_{i, t}}{M_{i, t-1}}+\gamma_{7} \frac{\Delta D_{i, t}}{M_{i, t-1}}+\gamma_{8} \frac{N F_{i, t}}{M_{i, t-1}} \\
& +\sum_{t=1}^{10} \text { Year }_{t}+\varepsilon_{i, t}
\end{aligned}
$$

The optimal contracting hypothesis suggests the more pronounced effect of pension incentive on the equity value of hedging to well-governed firms. Intuitively, since pension incentive is intended to dampen CEO incentives to pursue active risk management that largely benefits equity holders, the optimal contracting hypothesis predicts that pension benefit has a positive influence on the marginal relation between equity value and hedging in firms with stronger shareholder power. We report the result of above specification in Table 9. Remarkably, among the coefficients on the triple interaction terms for each of three pension incentive measures, we find that those that interacted with the above-median governance dummies are statistically significant, but those that interacted with the below-median governance dummies are not significant. For example (in Panel A), a significant coefficient of the triple interaction term (0.068) is found in the column of CEO Pension/Equity Compensation for the firms with governance measure above the median. From the column using the dummy variable of (CEO pension relative leverage greater than one) we also observe that the triple interaction term with the governance (>Median) has a significant coefficient of 0.068 . These results indicate that the marginal impact of pension incentive on value of hedging is higher for the firms with good governance structure or strong shareholder power. This finding is consistent with the optimal contracting hypothesis that the contract of liability-based incentive is an outcome of optimal governance structure, and the additional hedging amount promoted by such effective incentive creates more value for shareholders.

6 We also examine the results by using institutional blockholder ownership and observe the consistent results. These results are not reported for brevity. 
Table 9. The Value Creation of Pension Incentive through Hedging Interacted with Governance.

\begin{tabular}{|c|c|c|c|c|c|c|}
\hline \multicolumn{7}{|c|}{ Panel A: Value of Hedging Adoption Interacted with Governance } \\
\hline & \multicolumn{2}{|c|}{$\begin{array}{l}\text { CEO Pension/Equity } \\
\text { Compensation (\%) }\end{array}$} & \multicolumn{2}{|c|}{$\begin{array}{l}\text { CEO Pension Relative } \\
\text { Leverage }\end{array}$} & \multicolumn{2}{|c|}{$\begin{array}{l}\text { Dummy (CEO Pension } \\
\text { Relative Leverage }>1 \text { ) }\end{array}$} \\
\hline & Coef & T-stat & Coef & T-stat & Coef & T-stat \\
\hline 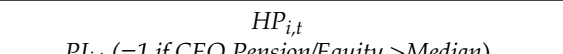 & $1.301^{* *}$ & $(1.993)$ & $1.306^{* *}$ & $(1.989)$ & 1.322 ** & $(1.991)$ \\
\hline $\begin{array}{c}P I_{i, t}(=1 \text { if CEO Pension/Equity }>\text { Median }) \\
P I_{i, t}(=1 \text { if } C E O \text { Pension Relative Leverage }>\text { Median })\end{array}$ & 0.023 & $(1.220)$ & 0.022 & $(1.242)$ & & \\
\hline$P I_{i, t}(=1$ if CEO Pension Relative Leverage $>1)$ & & & & & 0.049 & $(1.085)$ \\
\hline Governance $(>\text { Median })^{*} P I_{i, t}^{*} H P_{i, t}$ & $0.068^{* * *}$ & $(3.607)$ & & & & \\
\hline Governance $(<\text { Median })^{*} P I_{i, t}^{*} H P_{i, t}^{*}$ & 0.010 & $(0.096)$ & & & & \\
\hline Governance $(>\text { Median })^{*} P I_{i, t}^{*} H P_{i, t}$ & & & $0.060 *$ & $(1.921)$ & & \\
\hline Governance $(<\text { Median })^{*} \mathrm{PI}_{i, t}{ }^{*} H P_{i, t}$ & & & 0.053 & $(0.634)$ & & \\
\hline Governance $(>\text { Median })^{*} P_{i, t}^{*} H P_{i, t}$ & & & & & $0.074^{* *}$ & $(2.304)$ \\
\hline Governance $(<\text { Median })^{*} P I_{i, t}{ }^{*} H P_{i, t}$ & & & & & 0.051 & $(0.361)$ \\
\hline$L_{i, t}$ & $-0.638 * * *$ & $(-11.789)$ & $-0.632 * * *$ & $(-10.543)$ & $-0.644^{* * *}$ & $(-10.779)$ \\
\hline$\Delta C_{i, t} / M_{i, t-1}$ & $0.881^{* * *}$ & $(8.459)$ & $0.863^{* * *}$ & $(7.512)$ & $0.859^{* * *}$ & $(7.506)$ \\
\hline$\Delta E_{i, t} / M_{i, t-1}$ & $0.799^{* * *}$ & $(10.243)$ & $0.769 * * *$ & $(9.013)$ & $0.766^{* * *}$ & $(8.968)$ \\
\hline$\Delta N A_{i, t} / M_{i, t-1}$ & -0.044 & $(-1.030)$ & -0.039 & $(-0.825)$ & -0.039 & $(-0.838)$ \\
\hline$\Delta R D_{i, t} / M_{i, t-1}$ & -0.019 & $(-0.012)$ & -0.336 & $(-0.194)$ & -0.309 & $(-0.178)$ \\
\hline$\Delta I_{i, t} / M_{i, t-1}$ & -1.039 & $(-0.876)$ & -1.795 & $(-1.372)$ & -1.774 & $(-1.359)$ \\
\hline$\Delta D_{i, t} / M_{i, t-1}$ & $5.351 *$ & $(1.752)$ & 5.331 & $(1.566)$ & 5.423 & $(1.592)$ \\
\hline$N F_{i, t} / M_{i, t-1}$ & $0.110^{* * *}$ & $(6.244)$ & $0.116^{* * *}$ & $(6.008)$ & $0.116^{* * *}$ & (5.968) \\
\hline Year Controls & & & & & & \\
\hline $\mathrm{N}$ of Obs. & & & & & & \\
\hline Adjusted $\mathrm{R}^{2}$ & & & & & & \\
\hline \multicolumn{7}{|c|}{ Panel B: Regression of Pension Incentives on the Value of Hedging Intensity with Governance } \\
\hline & \multicolumn{2}{|c|}{$\begin{array}{c}\text { CEO Pension/Equity } \\
\text { Compensation (\%) }\end{array}$} & \multicolumn{2}{|c|}{$\begin{array}{c}\text { CEO Pension Relative } \\
\text { Leverage }\end{array}$} & \multicolumn{2}{|c|}{$\begin{array}{l}\text { Dummy (CEO Pension } \\
\text { Relative Leverage }>1 \text { ) }\end{array}$} \\
\hline & Coef & T-stat & Coef & T-stat & Coef & T-stat \\
\hline$H I_{i, t-1} / M_{i, t-1}$ & $0.276^{*}$ & $(1.908)$ & $0.283 *$ & $(1.855)$ & 0.224 & $(1.483)$ \\
\hline$\Delta H I_{i, t} / M_{i, t-1}$ & 0.037 & $(0.506)$ & 0.025 & $(0.205)$ & 0.059 & $(0.788)$ \\
\hline$P I_{i, t}(=1$ if CEO Pension/Equity $>$ Median $)$ & -0.018 & $(-0.278)$ & & & & \\
\hline$P I_{i, t}(=1$ if CEO Pension Relative Leverage $>$ Median $)$ & & & 0.024 & $(0.519)$ & & \\
\hline$P I_{i, t}(=1$ if $C E O$ Pension Relative Leverage $>1)$ & & & & & 0.055 & $(1.508)$ \\
\hline Governance $(>\text { Median })^{*} P I_{i, t}^{*}\left(\Delta H I_{i, t} / M_{i, t-1}\right)$ & $0.009^{* * *}$ & $(2.594)$ & & & & \\
\hline Governance $(<\text { Median })^{*} P I_{i, t}^{*}\left(\Delta H I_{i, t} / M_{i, t-1}\right)$ & 0.010 & $(0.096)$ & & & & \\
\hline Governance $(>\text { Median })^{*} P I_{i, t}^{*}\left(\Delta H I_{i, t} / M_{i, t-1}\right)$ & & & $1.213^{* *}$ & $(2.436)$ & & \\
\hline Governance $(<\text { Median })^{*} P I_{i, t}^{*}\left(\Delta H I_{i, t} / M_{i, t-1}\right)$ & & & 0.853 & $(0.634)$ & & \\
\hline Governance $(>\text { Median })^{*} P I_{i, t}^{*}\left(\Delta H I_{i, t} / M_{i, t-1}\right)$ & & & & & $1.297^{* * *}$ & $(2.578)$ \\
\hline Governance $(<\text { Median })^{*} P I_{i, t}^{*}\left(\Delta H I_{i, t} / M_{i, t-1}\right)$ & & & & & 1.051 & $(0.361)$ \\
\hline$L_{i, t}$ & $-0.467 * * *$ & $(-11.463)$ & $-0.486^{* * *}$ & $(-11.746)$ & $-0.492 * * *$ & $(-12.114)$ \\
\hline$\Delta C_{i, t} / M_{i, t-1}$ & $0.656^{* * *}$ & $(8.468)$ & $0.668^{* * *}$ & $(8.460)$ & $0.656^{* * *}$ & $(8.364)$ \\
\hline$\Delta E_{i, t} / M_{i, t-1}$ & $0.594^{* * *}$ & $(10.241)$ & $0.608^{* * *}$ & (10.263) & $0.606^{* * *}$ & (10.309) \\
\hline$\Delta N A_{i, t} / M_{i, t-1}$ & -0.033 & $(-1.034)$ & -0.034 & $(-1.058)$ & -0.036 & $(-1.120)$ \\
\hline$\Delta R D_{i, t} / M_{i, t-1}$ & -0.002 & $(-0.002)$ & -0.026 & $(-0.022)$ & -0.021 & $(-0.018)$ \\
\hline$\Delta I_{i, t} / M_{i, t-1}$ & -0.767 & $(-0.876)$ & -0.782 & $(-0.874)$ & -0.676 & $(-0.763)$ \\
\hline$\Delta D_{i, t} / M_{i, t-1}$ & $3.801 *$ & $(1.667)$ & $3.962 *$ & $(1.703)$ & 3.252 & $(1.409)$ \\
\hline$N F_{i, t} / M_{i, t-1}$ & $0.081^{* * *}$ & (6.165) & $0.082^{* * *}$ & $(6.080)$ & $0.083^{* * *}$ & $(6.262)$ \\
\hline Year Controls & \multicolumn{2}{|c|}{ Yes } & \multicolumn{2}{|c|}{ Yes } & \multicolumn{2}{|c|}{ Yes } \\
\hline $\mathrm{N}$ of Obs. & \multirow{2}{*}{\multicolumn{2}{|c|}{$\begin{array}{l}5869 \\
0.155\end{array}$}} & \multirow{2}{*}{\multicolumn{2}{|c|}{$\begin{array}{l}4962 \\
0.146\end{array}$}} & \multirow{2}{*}{\multicolumn{2}{|c|}{$\begin{array}{l}4962 \\
0.142\end{array}$}} \\
\hline Adjusted $\mathrm{R}^{2}$ & & & & & & \\
\hline
\end{tabular}

This table presents the OLS regressions of excess stock returns on CEO pension incentive and the changes in firm characteristics, including the explanatory variables from Faulkender and Wang (2006) specification augmented with the measures of pension incentive, hedging variables, and governance variable. Panel A examines the propensity of hedging $(H P)$ and Panel B examines the intensity of hedging $(H I)$. In all panels the dependent variable is the annual excess equity return calculated from a firm $i$ 's stock return over year $t-1$ to year $t, r_{i, t}$, net of $R_{r, t}^{B}$, the return of Fama and French (1993) size and book-to-market matched portfolio from year $t-1$ to year $t . \Delta X_{i, t}$ is the notation for the one-year change of variable $X$ for firm $i$ over year $t-1$ to year $t$, i.e., $X_{t}-X_{t-1} ; H I_{i, t}$ is hedging principal (dollar amount of total notional value of derivatives) at time $t$, and $\Delta H I_{i, t}=H I_{i, t}-H I_{i, t-1} ; M_{i, t}$ is market value of equity at time $t ; C_{i, t}$ is cash plus marketable securities; $E_{i, t}$ is earnings before extraordinary items plus interest, deferred tax credits, and investment tax credits; $N A_{i, t}$ is total assets minus cash holdings; $R D_{i, t}$ is research and development expense; $I_{i, t}$ is interest expense; $D_{i, t}$ is common dividends; $N F_{i, t}$ is total equity issuances minus repurchases plus debt issuances minus debt redemption; $L_{i, t}$ is the ratio of long-term debt plus debt in current liabilities divided by the market value of assets at time $t$; PI denotes one of three dummy proxies of pension incentive in each regression, namely, PI takes the value of one when CEO Pension/Equity is greater than the median value of this variable, and takes the value of one when CEO Pension Relative Leverage is above the median value or greater than one, respectively. Governance is a dummy variable that takes the value of one when Board Independence is greater than the median value, and zero otherwise. T-Statistics in the column next to the estimates are computed using robust standard errors. ${ }^{*}, * *$ and ${ }^{* * *}$ denote significance at the $10 \%, 5 \%$ and $1 \%$ levels, respectively. 
Apparently, the tests based on hedging intensity in Panel B also report the consistent results of significantly strengthening influence of pension incentive on the value of hedging. For instance, when we use the dummy measure of CEO pension relative leverage, pension incentive significantly increases the value of hedging by USD 1.297 for the firms with strong governance but no significant value creation is found for the peers with weak governance. This result justifies our optimal contract hypothesis and, also, confirms our findings in Tables 6 and 7. With more influence of pension incentive, the marginal value creation of hedging attributed to such liability-based incentives is higher for firms with strong shareholder power.

\section{Conclusions}

In this paper, we empirically examine the influence of $\mathrm{CEO}$ pension incentive on corporate risk management activity by employing a sample of multinational firms over the period of 2006 to 2015 and across a wide array of industries. The results show a significantly positive impact of pension incentive on hedging activity. More liability-based incentives encourage managers to adopt hedging or/and increase hedging position. We also verify that such a positive relationship cannot be attributed to the endogenous issue of compensation design.

Furthermore, we find that the influence of pension incentive on hedging is more pronounced for the firms with good governance than those with poor governance. The results help untangle the role of compensation in the mechanism of governance by providing the evidence to support the optimal contracting hypothesis. Lastly, we further investigate the value of extra investment in hedging position by following Faulkender and Wang's (2006) methodology, especially in the context of pension incentive and corporate governance. We detect that a higher level of pension incentive is associated with the higher value of hedging, particularly for the firms with strong shareholder power. This result echoes the theory of optimal contracting.

Taken together, this research contributes to the extant literature on the role of pension incentive by providing new evidence about its economic influence on corporate risk management. Although the existing literature reports mixed results pertaining to equity-based incentives, the findings documented in this research clearly show that liability-based compensation creates a valuable incentive and has a material impact on firms' active risk management. Our results warrant further attention to the design of pension incentive and its interplay with corporate governance.

Author Contributions: Conceptualization, J.J.C., and I.T.; Methodology, J.J.C.; Software, J.J.C., and Y.G.; Investigation, J.J.C., and Y.G.; Data collection and preparation, J.J.C., Y.G., and I.T.; Review and validation, J.J.C. All authors have read and agreed to the published version of the manuscript.

Funding: This research received no external funding.

Conflicts of Interest: The authors declare no conflict of interest.

\section{Appendix A}

Table A1. Detailed definition of primary variables used in this study.

\begin{tabular}{cc}
\hline Variable Names & Variable Definitions \\
\hline Pension Incentive & $\begin{array}{c}\text { The sum of the aggregate actuarial present value of the CEO's accumulated benefits of } \\
\text { pension and the aggregate balance in non-tax-qualified deferred compensation plans at the } \\
\text { end of the fiscal year. }\end{array}$ \\
\hline $\begin{array}{c}\text { CEO Pension/Total } \\
\text { Compensation (\%) }\end{array}$ & $\begin{array}{l}\text { The value of CEO pension divided by CEO total compensation. Total CEO compensation } \\
\text { includes CEO pension, equity compensation, salary, bonus, long-term Incentive payouts, } \\
\text { and all other total. }\end{array}$ \\
$\begin{array}{c}\text { CEO Pension/Equity } \\
\text { Compensation (\%) }\end{array}$ & $\begin{array}{c}\text { Value of CEO pension divided by CEO equity compensation. Equity compensation is the } \\
\text { sum of the value of the CEO's common stock holdings plus the value of options based on } \\
\text { Black-Scholes, all measured at the fiscal year end. }\end{array}$ \\
\hline
\end{tabular}


Table A1. Cont.

\begin{tabular}{|c|c|}
\hline Variable Names & Variable Definitions \\
\hline $\begin{array}{l}\text { CEO Pension Relative } \\
\text { Leverage }\end{array}$ & $\begin{array}{l}=(\text { CEO pension/ CEO equity Compensation }) /(\text { firm debt/firm equity). CEO pension and } \\
\text { equity compensation are defined as above. Firm debt is sum of long term debt plus debt in } \\
\text { current Liabilities. Firm equity is common shares outstanding*stock price at the end of } \\
\text { fiscal year. }\end{array}$ \\
\hline $\begin{array}{l}\text { Dummy (CEO Pension } \\
\text { Relative Leverage }>1)\end{array}$ & $\begin{array}{c}\text { A dummy variable which takes value of one if CEO-firm D/E ratio is greater than one. } \\
\text { Otherwise zero. }\end{array}$ \\
\hline \multicolumn{2}{|l|}{ Hedging Variables } \\
\hline $\begin{array}{l}\text { Currency Hedging } \\
\text { Propensity }\end{array}$ & $\begin{array}{c}\text { The dummy variable that takes a value of one when a firm holds or trades foreign currency } \\
\text { derivatives for hedging in a given year, and zero otherwise. }\end{array}$ \\
\hline $\begin{array}{l}\text { Currency Hedging } \\
\text { Intensity }\end{array}$ & $\begin{array}{l}\text { Total notional value of foreign currency derivatives for hedging in scaled by the book value } \\
\text { of total assets. }\end{array}$ \\
\hline \multicolumn{2}{|l|}{ CEO-Equity Incentive } \\
\hline Delta Incentive & $\begin{aligned}= & {[\partial \text { (option value }) / \partial(\text { stock price })]^{*}(\text { price } / 100)=\exp \left(-\mathrm{d}^{*} \mathrm{~T}\right)^{*} \mathrm{~N}(\mathrm{Z})^{*}(\text { price } / 100) \text {. Particularly, } } \\
& \text { it's defined as the change in option portfolio value for a } 1 \% \text { change in the stock price. }\end{aligned}$ \\
\hline Vega Incentive & $\begin{array}{c}=[\partial(\text { option value }) / \partial(\text { stock volatility })]^{*} 0.01=\exp \left(-\mathrm{d}^{*} \mathrm{~T}\right) \mathrm{N}^{\prime}(\mathrm{Z})^{*} \mathrm{~S}^{*} \mathrm{~T}^{*}(1 / 2)^{*}(0.01) \text {. Particularly, } \\
\text { it's defined as the change in option portfolio value for a } 0.01 \text { change in the annualized } \\
\text { standard deviation of stock return. }\end{array}$ \\
\hline $\begin{array}{l}\text { Vega Incentive/Delta } \\
\text { Incentive }\end{array}$ & $\begin{array}{l}\text { Rogers (2002) proposes that delta and Vega measure managerial motivation from } \\
\text { "value-creating" and "risk-taking" incentives, respectively. However, economic } \\
\text { interpretation of the ratio of Vega to delta should be more intuitive because it measures the } \\
\text { CEO risk-taking incentive per dollar of value-increasing incentives from option and stock } \\
\text { holdings. Rogers (2002) demonstrates this ratio has more explanatory power than either } \\
\text { Delta or Vega. }\end{array}$ \\
\hline \multicolumn{2}{|l|}{$\begin{array}{l}\text { Firm-related } \\
\text { Characteristics }\end{array}$} \\
\hline Log (Total Assets) & The logarithm of firm total assets adjusted with 2015 CPI. \\
\hline Leverage & $\begin{array}{c}=(\text { long term debt }+ \text { debt in current liability }) / \text { market value of total assets, where market } \\
\text { value of assets is the sum of total debt and market value of equity. }\end{array}$ \\
\hline Market-to-book Ratio & $\begin{array}{l}=\text { market value of Total assets/book value of total assets. market value of assets is the sum } \\
\text { of Total debt and market value of equity. }\end{array}$ \\
\hline Interest Coverage & $=$ EBITDA/Interest paid \\
\hline Tangible Assets Ratio & A ratio of tangible assets relative to firm total assets \\
\hline $\begin{array}{l}\text { Corr(Cash Flow, } \\
\text { Investment) }\end{array}$ & $\begin{array}{l}\text { The correlation coefficient between cash flow and investment expense. The calculation of } \\
\text { cash flow is following Lang et al. (1991) as: Operating income before depreciation-interest } \\
\text { expense-(income taxes-deferred tax change)-common dividends-preferred dividends. } \\
\text { The investment expense is following Gay and Nam (1998) to define as the sum of capital } \\
\text { expenditure, R\&D expense and net PP\&E. }\end{array}$ \\
\hline Cash Holding & The value of cash and short term security scaled by firm total assets \\
\hline Convertible Bonds Ratio & The value of convertible bond scaled by firm total assets \\
\hline $\begin{array}{l}\text { Positive Tax Credit } \\
\text { (Dummy) }\end{array}$ & The dummy variable of one if the firm has non-zero tax loss carry-forwards. \\
\hline Tax Convexity (MUSD) & $\begin{array}{c}\left.=4.88+7.15^{*} \text { (indicator variable of small negative taxable income }\right)+1.6^{*} \text { (indicator variable } \\
\text { of small positive taxable income })+0.019 * \text { (absolute coefficient of variation of pervious } \\
\text { taxable income })-5.5 * \text { (first-order serial correlation of taxable income })-1.28^{*}(\text { indicator } \\
\text { variable of investment tax credit })+(\text { indicator variable of net operating loss } \\
\text { carry-forward })^{*}\left(3.29-4.77^{*}(\text { indicator variable of small negative taxable income })\right)-1.93 \\
*(\text { indicator variable of small positive taxable income). It measures expected percentage tax } \\
\text { savings from a } 5 \% \text { reduction in the volatility of taxable income. Graham and Smith }(1999) \\
\text { use simulation to illustrate that this proxy is more precise to capture the shape of tax } \\
\text { function than tax loss carry-forward. }\end{array}$ \\
\hline Board Independence & The proportion of directors who are classified as outside directors serving on the board. \\
\hline $\begin{array}{l}\text { Institutional Blockholder } \\
\text { Ownership }\end{array}$ & $\begin{array}{c}\text { Defined as the sum of all ownership positions greater than or equal to } 5 \% \text { held by } \\
\text { institutional investors. }\end{array}$ \\
\hline
\end{tabular}




\section{References}

Anantharaman, Divya, and Yong Gyu Lee. 2014. Managerial risk taking incentives and corporate pension policy. Journal of Financial Economics 111: 328-51. [CrossRef]

Anantharaman, Divya, Vivian. W. Fang, and Guojin Guong. 2014. Inside debt and the design of corporate debt contracts. Management Science 60: 1260-80. [CrossRef]

Bebchuk, Lucian A., and Jesse M. Fried. 2004. Pay without Performance. Cambridge: Harvard University Press.

Belkhir, Mohamed, and Sabri Boubaker. 2013. CEO inside debt and hedging decisions: Lessons from the US banking industry. Journal of International Financial Markets, Institutions and Money 24: 223-46. [CrossRef]

Bereskin, Frederick L., and David C. Cicero. 2013. CEO compensation contagion: Evidence from an exogenous shock. Journal of Financial Economics 107: 477-93. [CrossRef]

Billett, Matthew T., David C. Mauer, and Yilei Zhang. 2010. Stockholder and bondholder wealth effects of CEO incentive grants. Financial Management 39: 463-87. [CrossRef]

Bodnar, Gordon M., Gregory S. Hayt, and Richard C. Marston. 1998. Wharton survey of financial risk management by US non-financial firms. Financial Management 27: 70-91. [CrossRef]

Brown, Charles, and James L. Medoff. 2003. Firm age and wages. Journal of Labor Economics 21: 677-97. [CrossRef]

Campello, Murillo, Chen Lin, Yue Ma, and Hong Zou. 2011. The real and financial implications of corporate hedging. Journal of Finance 66: 1615-47. [CrossRef]

Carpenter, Jennifer N. 2000. Does option compensation increase managerial risk appetite? Journal of Finance 55: 2311-31. [CrossRef]

Cassell, Cory A., Shawn X. Huang, Juan Manuel Sanchez, and Michael D. Stuart. 2012. Seeking safety: The relation between CEO inside debt holdings and the riskiness of firm investment and financial policies. Journal of Financial Economics 103: 588-610. [CrossRef]

Chen, Jun, and Tao-Hsien Dolly King. 2014. Corporate hedging and the cost of debt. Journal of Corporate Finance 29: 221-45. [CrossRef]

Coles, Jeffrey L., Naveen D. Daniel, and Lalitha Naveen. 2006. Managerial incentives and risk-taking. Journal of Financial Economics 79: 431-68. [CrossRef]

Croci, Ettore, Alfonso Del Giudice, and Håkan Jankensgård. 2017. CEO age, risk incentives, and hedging strategy. Financial Management 46: 687-716. [CrossRef]

Doukas, John A., and Christos Pantzalis. 2003. Geographic diversification and agency costs of debt of multinational firms. Journal of Corporate Finance 9: 59-92. [CrossRef]

Edmans, Alex, and Qi Liu. 2011. Inside Debt. Review of Finance 15: 75-102. [CrossRef]

Fama, Eugene F., and Kenenth R. French. 1993. Common risk factors in the returns on stocks and bonds. Journal of Financial Economics 33: 3-56. [CrossRef]

Faulkender, Michael, and Rong Wang. 2006. Corporate financial policy and the value of cash. Journal of Finance 61: 1957-90. [CrossRef]

Financial Accounting Standards Board. 1976. Reasonable Estimation of the Amount of a Loss: An Interpretation of FASB Statement No. 5. Norwalk: Financial Accounting Standards Board.

Froot, Kenneth, David S. Scharfstein, and Jeremy C. Stein. 1993. Risk management: Coordinating investment and financing policies. Journal of Finance 48: 1629-58. [CrossRef]

Gay, Gerald D., and Jouahn Nam. 1998. The underinvestment problem and corporate derivatives use. Financial Management 27: 53-69. [CrossRef]

Géczy, Christopher, Bernadette A. Minton, and Catherine Schrand. 1997. Why firms use currency derivatives? Journal of Finance 52: 1323-54.

Géczy, Christopher, Bernadette A. Minton, and Catherine Schrand. 2007. Taking a view: Corporate speculation, governance and Compensation. Journal of Finance 52: 2405-43. [CrossRef]

Gerakos, Joseph. 2010. Chief executive officer and the pay-pension tradeoff. Journal of Pension Economics and Finance 9: 303-19. [CrossRef]

Gormley, Todd A., David A. Matsa, and Todd Milbourn. 2013. CEO compensation and corporate risk: Evidence from a natural experiment. Journal of Accounting and Economics 56: 79-101. [CrossRef]

Graham, John R., and Daniel A. Rogers. 2002. Do firms hedge in response to tax incentives? Journal of Finance 57: 815-39. [CrossRef] 
Graham, John R., and Clifford W. Smith Jr. 1999. Tax incentives to hedge. Journal of Finance 54: 2241-62. [CrossRef] Greene, William H. 2004. Econometric Analysis. Upper Saddle River: Prentice Hall.

Guay, W. 1999. The sensitivity of CEO wealth to equity risk: An analysis of the magnitude and determinants. Journal of Financial Economics 53: 43-71. [CrossRef]

Halford, Joseph T., and Mingming Qiu. 2012. Inside Debt and Debt Incentives: Evidence from the 2008 Financial Crisis. Working Paper. Milwaukee, WI, USA: University of Wisconsin Milwaukee.

Hirshleifer, David, and Yoon Suh. 1992. Risk, managerial effort, and project choice. Journal of Financial Intermediation 2: 308-45. [CrossRef]

Jensen, Michael C., and Kevin J. Murphy. 1990. Performance pay and top management incentives. Journal of Political Economy 98: 225-64. [CrossRef]

Jensen, Michael C., and William H. Meckling. 1976. Theory of the firm: Managerial behavior, agency costs and ownership structure. Journal of Financial Economics 3: 305-60. [CrossRef]

Jenter, Dirk, and Katharina Lewellen. 2015. CEO preferences and acquisitions. Journal of Finance 70: $2813-52$. [CrossRef]

Kim, E. Han, and Yao Lu. 2011. CEO ownership, external governance, and risk-taking. Journal of Financial Economics 102: 272-92. [CrossRef]

Knopf, John D., Jouahn Nam, and John H. Thornton Jr. 2002. The volatility and price sensitivities of managerial stock option portfolios and corporate hedging. Journal of Finance 57: 801-13. [CrossRef]

Krapl, Alain A., and Reilly S. White. 2016. Executive pensions, risk-shifting, and foreign exchange exposure. Research in International Business and Finance 38: 376-92. [CrossRef]

Lang, Larry H. P., René M. Stulz, and Ralph A. Walkling. 1991. A test of the free cash flow hypothesis: The case of bidder returns. Journal of Financial Economics 29: 315-35. [CrossRef]

Lee, Gemma, and Hongfei Tang. 2011. CEO Pension and Deferred Compensation. Working Paper. South Orange, NJ, USA: Seton Hall University.

Lewellen, Katharina. 2006. Financing decisions when managers are risk-averse. Journal of Financial Economics 82: 551-89. [CrossRef]

Liu, Yixin, and David C. Mauer. 2011. Corporate cash holdings and CEO compensation incentives. Journal of Financial Economics 102: 183-98. [CrossRef]

Liu, Yixin, David C. Mauer, and Yilei Zhang. 2014. Firm cash holdings and CEO inside debt. Journal of Banking and Finance 42: 83-100. [CrossRef]

Myers, Stewart. 1977. Determinants of corporate borrowing. Journal of Financial Economics 5: 147-75. [CrossRef]

Nance, Deana R., Clifford W. Smith Jr., and Charles W. Smithson. 1993. On the determinants of corporate hedging. Journal of Finance 48: 267-84. [CrossRef]

Peng, Lin, and Alisa Roell. 2014. Managerial Incentives and Stock Price Manipulation. Journal of Finance 69: 487-526. [CrossRef]

Rajgopal, Shivaram, and Terry Shevlin. 2002. Empirical evidence on the relation between stock option compensation and risk taking. Journal of Accounting and Economics 33: 145-71. [CrossRef]

Roberts, Michael R., and Toni M. Whited. 2013. Endogeneity in empirical corporate finance. Handbook of the Economics of Finance 2: 493-572. [CrossRef]

Rogers, Daniel A. 2002. Does executive portfolio structure affect risk management? CEO risk-taking incentives and corporate derivatives usage. Journal of Banking and Finance 80: 271-95. [CrossRef]

Serfling, Matthew A. 2014. CEO age and the riskiness of corporate policies. Journal of Corporate Finance 25: 251-73. [CrossRef]

Smith, Clifford W., and Rene M. Stulz. 1985. The determinants of firms' hedging policies. Journal of Financial and Quantitative Analysis 28: 391-405. [CrossRef]

Sundaram, Rangarajan K., and David L. Yermack. 2007. Pay me later: Inside debt and its role in managerial compensation. Journal of Finance 62: 1551-88. [CrossRef]

Tan, Christine E. L., and Susan M. Young. 2016. Share repurchase choice and executive pension compensation. Journal of Management Accounting Research 28: 127-49. [CrossRef] 
Wei, Chenyang, and David L. Yermack. 2011. Investor reactions to CEOs' inside debt incentives. Review of Financial Studies 24: 3813-40. [CrossRef]

White, Reilly S. 2012. Three essays on inside debt. Working Paper. Storrs, CT, USA: University of Connecticut.

Yim, Soojin. 2013. The acquisitiveness of youth: CEO age and acquisition behavior. Journal of Financial Economics 108: 250-73. [CrossRef] 